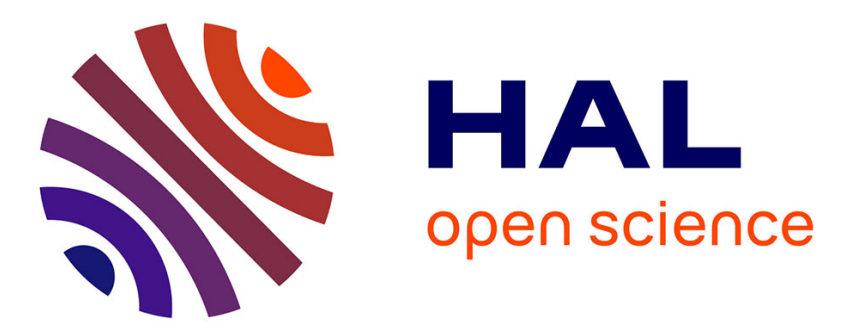

\title{
Mastitis impact on technological properties of milk and quality of milk products-a review
}

Le Maréchal, Thiéry, Vautor, Le Loir

\section{To cite this version:}

Le Maréchal, Thiéry, Vautor, Le Loir. Mastitis impact on technological properties of milk and quality of milk products-a review. Dairy Science \& Technology, 2011, 91 (3), pp.247-282. 10.1007/s13594011-0009-6 . hal-00930618

\section{HAL Id: hal-00930618 \\ https://hal.science/hal-00930618}

Submitted on 1 Jan 2011

HAL is a multi-disciplinary open access archive for the deposit and dissemination of scientific research documents, whether they are published or not. The documents may come from teaching and research institutions in France or abroad, or from public or private research centers.
L'archive ouverte pluridisciplinaire HAL, est destinée au dépôt et à la diffusion de documents scientifiques de niveau recherche, publiés ou non, émanant des établissements d'enseignement et de recherche français ou étrangers, des laboratoires publics ou privés. 


\title{
Mastitis impact on technological properties of milk and quality of milk products-a review
}

\author{
Caroline Le Maréchal • Richard Thiéry • \\ Eric Vautor • Yves Le Loir
}

Received: 6 April 2010 /Revised: 6 September 2010 /Accepted: 17 September 2010 / Published online: 11 March 2011

(C) INRA and Springer Science+Business Media B.V. 2011

\begin{abstract}
The consequences of mastitis on the technological properties of milk and on the quality of milk products are widely reported in the literature. Besides, recent advances have shed light on the mechanisms involved in the udder response and subsequent milk changes in mastitis cases. This review gives an update on the literature regarding the impact of mastitis on milk composition and processing properties and collates recent data regarding the mechanisms involved in mastitis effects. It is an attempt to link field observations and experimental studies in order to better understand how mastites affect so dramatically the technological properties of milk. Both bovine and small ruminant milks are considered and a special emphasis is given on the role of staphylococci, streptococci, and Escherichia coli, the most common causative agents of mastitis.
\end{abstract}

\section{乳腺炎对乳制品质量和乳加工特性的影响}

摘要关于乳房炎对乳的加工特性和乳制品质量影响的文献报道非常多。近年来关于此方面 的研究重点在乳房炎对乳房的反应以及对影响乳成分变化的机制。本文对近年来乳房炎对 乳组成和加工特性的影响及其影响机制方面的相关文献进行了对比和分析。目的是说明乳 房炎的发生会对乳的加工特性产生巨大的作用。不但是对牛乳, 而且一些小反刍动物乳的加

C. Le Maréchal • Y. Le Loir $(\square)$

INRA, UMR1253 STLO, 65 rue de Saint Brieuc, F-35042 Rennes, France

e-mail: yves.leloir@rennes.inra.fr

C. Le Maréchal · Y. Le Loir

Agrocampus Ouest, UMR1253 STLO, 65 rue de Saint Brieuc, F-35042 Rennes, France

C. Le Maréchal $\cdot$ R. Thiéry

ANSES, Laboratoire d'études et de recherches des ruminants, 105 route des Chappes, F-06902 Sophia-Antipolis, France

Present Address:

E. Vautor

LVD06, F-06902 Sophia-Antipolis, France 
工特性都受乳房炎的影响。值得强调的一个现象是葡萄球菌、链球菌属和大肠杆菌是乳房 炎发病最主要的原因。

Keywords Mastitis $\cdot$ Milk $\cdot$ Ruminant $\cdot$ Dairy product $\cdot$ Bacterial pathogen

关键词 乳・反刍动物・乳制品·致病细菌

\section{Introduction}

Milk composition can be affected by a wide array of factors: breed, age, stage of lactation, and diet of the animal. In addition, infectious mastitis (hereafter referred to as mastitis), an inflammatory reaction of the mammary gland to an infection, is also known to have a multitude of effects on the quantity, quality, and processing properties of the produced milk. Mastitis is the most frequent disease in dairy herds and is the main source of economic loss in milk production worldwide. The average annual cost of mastitis caused by Staphylococcus aureus, Streptococcus agalactiae, Streptococcus uberis, and Escherichia coli is estimated to be 4,896 € in a herd of 100 dairy cows (Halasa et al. 2009). Beyond animal health and food safety issues, mastitis is also a problem for the dairy industry because of the induced milk changes. This review gives an update of the literature regarding the impact of mastitis on milk composition and processing properties and collates recent data regarding the mechanisms involved in these effects. Staphylococci, streptococci, and E. coli are the most common causative bacterial agents of mastitis in both bovine and small ruminant hosts and therefore have been more documented. Special emphasis is given to the impact on milk quality and technological properties.

\section{Milk and milk product changes caused by mastitis}

\subsection{Milk changes}

\subsubsection{High somatic cell count as a marker of mastitis}

Many reports have described the changes in milk yield and or composition associated with mastitis. Regarding quality control, the increase of somatic cell count (SCC) in milk is the main marker for the detection and diagnosis of mastitis (Viguier et al. 2009). The direct link between changes in SCC and the onset of mastitis has indeed been known for a long time. Therefore, in a wide array of scientific reports, authors have considered an increase in SCC as a marker of mastitis and the identification of the bacterial species causing the mastitis was most often neglected. However, recent data regarding the pathogenesis of mastitis has shown that the effects of mastitis on milk yield and composition may vary greatly with regard to the causative agent. These differences may in turn explain some previous conflicting reports in the field.

The host immune response to the different pathogens appears to vary among species (Bannerman et al. 2004b; Leitner et al. 2006) and each pathogen induces specific changes in the milk (Leitner et al. 2006). Normal SCC is 68,000 cells $\cdot \mathrm{mL}^{-1}$ in cows 
milk (Djabri et al. 2002), around 75,000 cells $\cdot \mathrm{mL}^{-1}$ in ewes milk (Ariznabarreta et al. 2002; Gonzalo et al. 2002) and varies between 210,000 and $1,120,000$ cells $\cdot \mathrm{mL}^{-1}$ in goats milk (Leitner et al. 2004c; Manser 1986). A meta-analysis of the data concerning the rise in SCC during mastitis infection in cows has actually shown differences depending on the pathogen involved. SCC range from 105,000 cells $\cdot \mathrm{mL}^{-1}$ in Corynebacterium bovis mastitis up to $1,151,000$ cells $\cdot \mathrm{mL}^{-1}$ in E. coli mastitis (Djabri et al. 2002). The two other major pathogens, $S$. aureus and $S$. uberis induce a SCC increase of 357,000 cells and 1,024,000 cells $\cdot \mathrm{mL}^{-1}$, respectively (Djabri et al. 2002).

The rise in SCC also varies depending on the causative pathogen during mastitis in small ruminants. In ewes, the SCC ranges from 187,000 cells $\cdot \mathrm{mL}^{-1}$ in Corybacterium spp. mastitis up to $7,461,000$ cells $\cdot \mathrm{mL}^{-1}$ in Pasteurella spp. or $S$. agalactiae mastitis (Gonzalo et al. 2002). Coagulase negative staphylococci (CNS), micrococci, and corynebacteria induce mastitis with SCC under 200,000 cells $\cdot \mathrm{mL}^{-1}$ (Raynal-Ljutovac et al. 2007). In S. aureus mastitis, SCC varies between 3,035,000 and 4,800,000 cells $\cdot \mathrm{mL}^{-1}$ according to studies (Ariznabarreta et al. 2002; Gonzalo et al. 2002) (No data are available for E.coli and S. uberis). In goats milk, SCC ranges from 444,000 to $1,480,000$ cells $\cdot \mathrm{mL}^{-1}$ in CNS mastitis and rises to above $3,000,000$ cells $\cdot \mathrm{mL}^{-1}$ in $S$. aureus mastitis (Leitner et al. 2004c; Manser 1986). Variations in the SCC can be observed during mastitis with a specific profile for each pathogen. For example in coliform mastitis, the SCC is low before and after the clinical mastitis. On the contrary, in the case of clinical $S$. aureus mastitis, the SCC increases before and remains high after cure. In the same way, streptococci induce a continuous rise in SCC until clinical mastitis is settled and the SCC remains at a high level after mastitis (de Haas et al. 2002).

Different pathogens can also induce different symptoms and can be associated with different types of mastitis. Mastites indeed range from subclinical mastitis to clinical mastitis. These latter clinical mastites can be classified into mild, moderate, and severe mastitis (Table 1). In small ruminants, severe clinical mastitis can turn into gangrenous mastitis with the destruction of tissues and loss of the infected udder. A given pathogen

Table 1 Definition of the mastitis types with regard to the severity of the symptoms

\begin{tabular}{ll}
\hline Mastitis type & Definition $^{\text {a }}$ \\
\hline Subclinical mastitis & $\begin{array}{c}\text { Inflammation of the mammary gland that is not visible and requires a diagnostic test for } \\
\text { detection. The most used diagnostic test is the milk somatic cell count. Subclinical } \\
\text { mastitis is the most prevalent form of the disease }\end{array}$ \\
$\begin{array}{l}\text { Mild clinical } \\
\text { mastitis }\end{array}$ & $\begin{array}{l}\text { no signs of swelling of the mammary glands or systemic illness. } \\
\text { Preferred terminology when describing severity of clinical cases }\end{array}$ \\
$\begin{array}{c}\text { Moderate clinical } \\
\text { mastitis }\end{array}$ & $\begin{array}{l}\text { Visibly abnormal milk accompanied by swelling in the infected } \\
\text { mammary quarter with an absence of systemic signs of illness. }\end{array}$ \\
& $\begin{array}{l}\text { The terminology is preferred when describing the severity of } \\
\text { clinical symptoms }\end{array}$ \\
Severe clinical & $\begin{array}{c}\text { Udder inflammation characterized by sudden onset with grave systemic } \\
\text { and local symptoms. This terminology is preferred to peracute clinical mastitis }\end{array}$
\end{tabular}

${ }^{a}$ According to the mastitis terminology as defined in the Bulletin of the International Dairy Federation $338 / 1999$ 
(for example $S$. aureus) can be associated with different types of mastitis, notably in small ruminants (Vautor et al. 2009). Consequences of each type of mastitis on milk quality will differ. For example, clots appear in milk from animals with clinical mastitis whereas none are present in milk from animals with subclinical mastitis. In the same way, mastitis can affect all quarters or only one (with the others remaining healthy).

It also appears that the SCC is not a good criterion to diagnose mastitis in goats. The SCC level in goats milk is indeed prone to significant changes through the lactation period (Galina et al. 1996; Haddadi et al. 2006). In nonmastitic goats milk, the SCC can vary between 200,000 to 500,000 cells at the beginning of lactation, to 200,000 to 350,000 in the peak of lactation and to $1,000,000$ to $3,100,000$ or more at the end (Bergonier et al. 1994). It has recently been reported that no changes in goats milk composition is observed when the SCC varies from 214,000 to 1450,000 cells $\cdot \mathrm{mL}^{-1}$ (Chen et al. 2010). The changes in milk presented in this paragraph are associated with a high SCC level but it has to be noted that these changes cannot be assigned to a clear and demonstrated onset of mastitis. In this paragraph, available data in the literature regarding the changes observed in cows, ewes, and goats milks when the SCC (regarded as a mastitis marker) increases will be summarised. Data regarding small ruminant milk changes are fewer than these for cows milk which are reported in more detail.

\subsubsection{Negative correlation between SCC and milk yield}

Regardless of the ruminant species, an increase in the SCC in bulk milk is generally associated with a decrease in milk yield (Barlowska et al. 2009; Baudry et al. 1997; Caruolo 1974; El-Saied et al. 1999; Gonzalo et al. 1994; Leitner et al. 2003; 2004a, b; Munro et al. 1984; Othmane et al. 2002; Pellegrini et al. 1997; Pizzillo et al. 1996; Ying et al. 2002; Zeng and Escobar 1996). The decrease in cows milk yield is observed at least 1 week before clinical mastitis is diagnosed (Bareille et al. 2003; Grohn et al. 2004; Hagnestam et al. 2007; Lucey et al. 1986; Ostergaard and Grohn 1999; Rajala-Schultz et al. 1999; Wilson et al. 2004). This time lag is probably due to the fact that mastitis is subclinical before the onset of clinical symptoms (Hagnestam et al. 2007). The period of lactation modulates the impact of mastitis. The effects of mastitis on production yields are indeed more severe when the mastitis developed in early lactation before the peak yield (Bartlett et al. 1991; Hortet and Seegers 1998; Rajala-Schultz et al. 1999; Santos et al. 2004; Wilson et al. 2004). Lower production yields are also a consequence of mastitis. After clinical mastitis, cows produce less milk throughout the rest of lactation in comparison to cows without mastitis (Bareille et al. 2003; Hagnestam et al. 2007; Wilson et al. 2004) and never return to their premastitic milk yield levels (Grohn et al. 2004; Wilson et al. 2004).

In cows, milk yield losses vary with the species of causative agent: among primipara, S. aureus, Arcanobacterium pyogenes, E. coli, Klebsiella spp. caused the greatest losses; among multipara, Streptococcus spp., S. aureus, A. pyogenes, E. coli, and Klebsiella spp. caused the most significant losses. Milk loss persisted until at least 70 days after diagnosis for Streptococcus spp., Klebsiella spp., and $A$. pyogenes. (Grohn et al. 2004). Loss in milk yield in E. coli clinical mastitis is $15 \mathrm{~kg}$ per day, whereas it is $1.6 \mathrm{~kg}$ per day in $S$. aureus clinical mastitis and $2.9 \mathrm{~kg}$ per day in $S$. uberis clinical mastitis (Coulon et al. 2002). Gram-negative cases had more severe milk loss (304 kg in multipara and $228 \mathrm{~kg}$ in primipara in the 50 days following 
clinical mastitis) compared with gram-positive ones (128 kg in multipara and $133 \mathrm{~kg}$ in primipara in the 50 days following clinical mastitis) (Schukken et al. 2009).

In ewes, milk yield loss varies according to the causative pathogen and to unilateral or bilateral character of mastitis and ranges from $3 \%$ to $10 \%$. Healthy ewes produce $880 \mathrm{~mL}$ of milk per day whereas ewes infected by major pathogens with bilateral mastitis produce $791 \mathrm{~mL}$ per day (Gonzalo et al. 2002). Even during subclinical mastitis, milk yield of the infected halves $(0.36 \mathrm{~kg} / \mathrm{milking})$ significantly decreases $(P<0.001)$ in comparison to the milk yield of the uninfected halves $(0.76 \mathrm{~kg} / \mathrm{milking})$ (Leitner et al. 2004a). This has also been described in goats, where milk yield decreases during subclinical mastitis $(0.69 \mathrm{~kg} /$ milking in goats with mastitis compared with $0.98 \mathrm{~kg} /$ milking in healthy goats) (Leitner et al. 2004b).

\subsubsection{Changes in milk associated with a rise in the SCC and variations according to pathogens}

Global changes All available data concerning changes in milk due to mastitis are summarized in Table 2, many of which have already been reviewed (Auldist and Hubble 1998; Raynal-Ljutovac et al. 2007). In summary, it has clearly been determined that regardless of the ruminant species, there is a rise in the level of whey proteins (notably in serum albumin and $\mathrm{IgG}$ ) and in sodium and a decrease in the level of lactose (except for goats milk for which the results are conflicting). Globally, there is a rise in the level of proteins and proteinous compounds linked to the inflammatory and immune response and a decrease in the endogenous milk proteins such as caseins. Some of the changes in milk composition appear to be advantageous for the defense of the mammary gland against bacterial pathogens (Schmitz et al. 2004). For example, a rise in the level of $\operatorname{IgG} 2$, which are opsonic antibodies has been observed, as has the level of lactoferrin, which has bacteriostatic activities while a decrease has been observed in the level of caseins, which normally inhibit the myeloperoxidase-mediated oxygen-dependent bactericidal activity of neutrophils (Cooray 1996; Watanabe et al. 2000). An effect of the SCC on milk pH has also been reported in cows, goats, and ewes milk which increases with increasing SCC (Raynal-Ljutovac et al. 2007; Vianna et al. 2008).

Data concerning the impact of mastitis on the total content of protein, fat and calcium are conflicting and no trends for these parameters can be determined at the moment. A clear and noncontroversial effect is a change in the protein profile: a rise in the level of whey proteins (with a change in whey protein composition) and changes in the casein profile. The impact of mastitis on caseins depends on the species of ruminant. Mastitic cows milk shows a decrease in casein (a decrease in $\beta$ and $\alpha$-caseins, an increase in $\gamma$-casein) whereas the impact on ewes milk appears variable while no impact has been observed on goats milk. Beside casein concentration, it seems that mastitis affects the casein composition: concentration of soluble caseins has been shown to be higher and concentration of micellar caseins to be lower in mastitic milk than in healthy milk (detected by Wisconsin mastitis test) (Sharma and Randolph 1974). These phenomena can result from the regulation of the "lactation" genes in response to infection and from the induced hydrolysis of milk proteins observed when the SCC slightly increases, with or without clinical signs (Le Roux et al. 1995; Urech et al. 1999). 


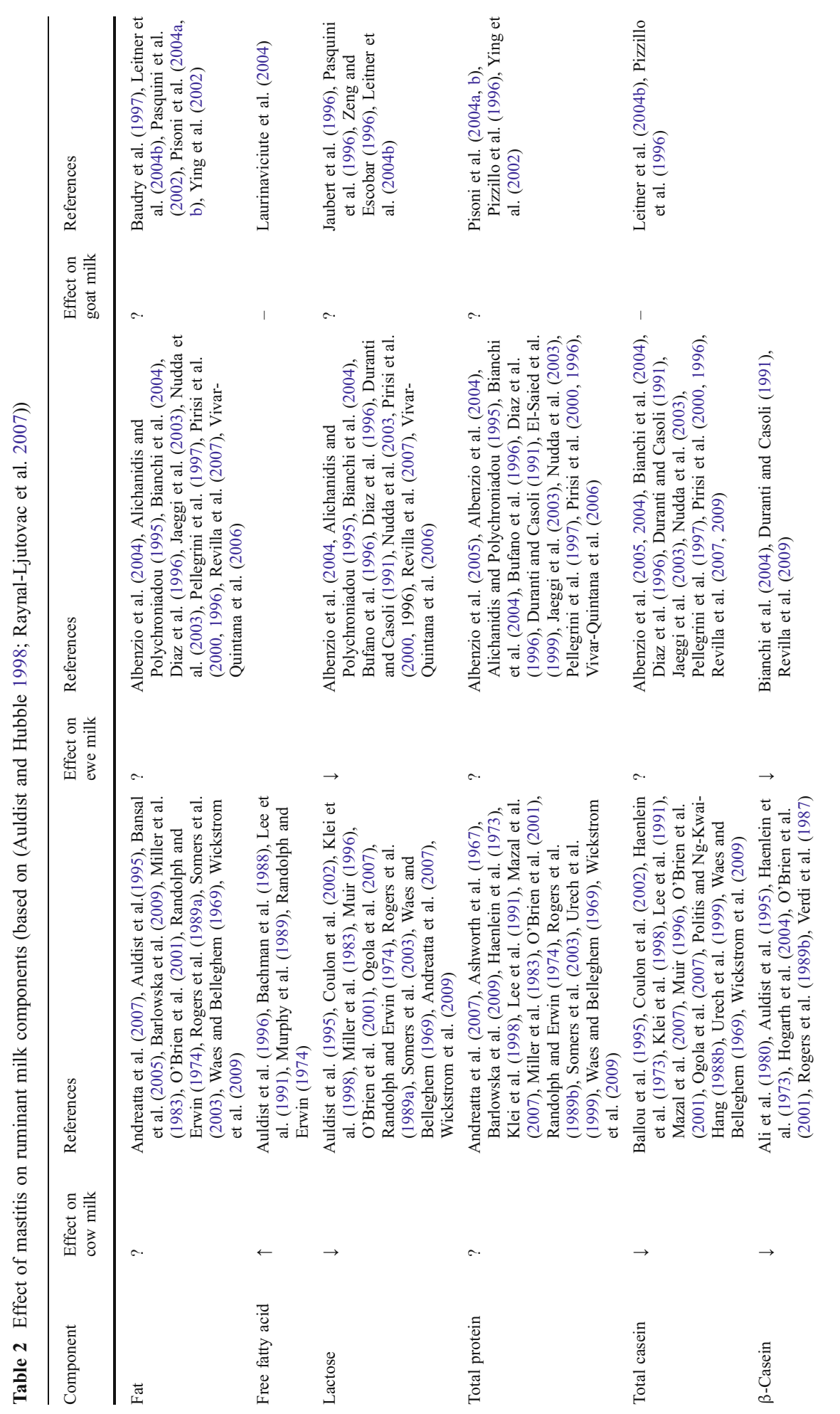



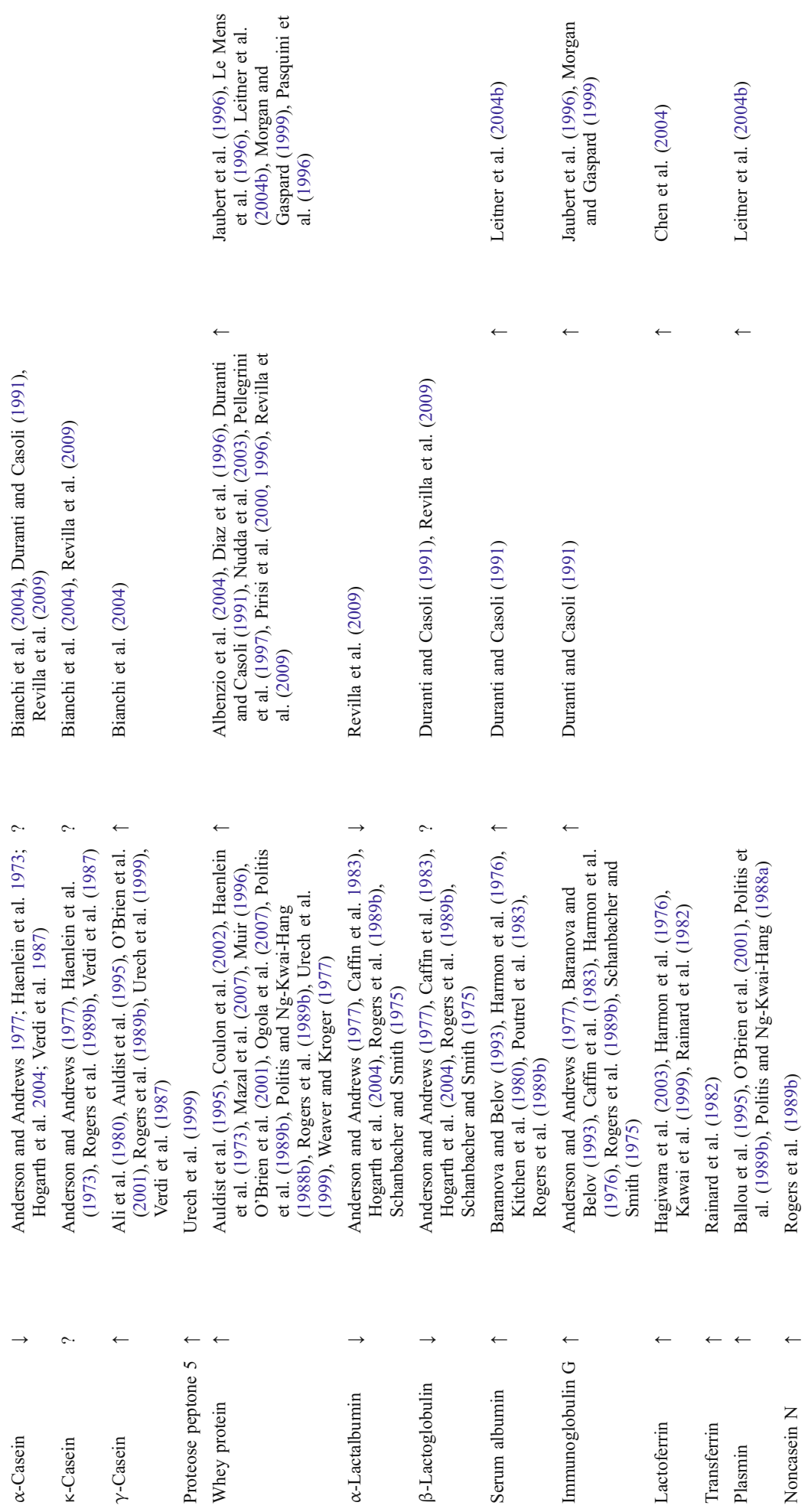


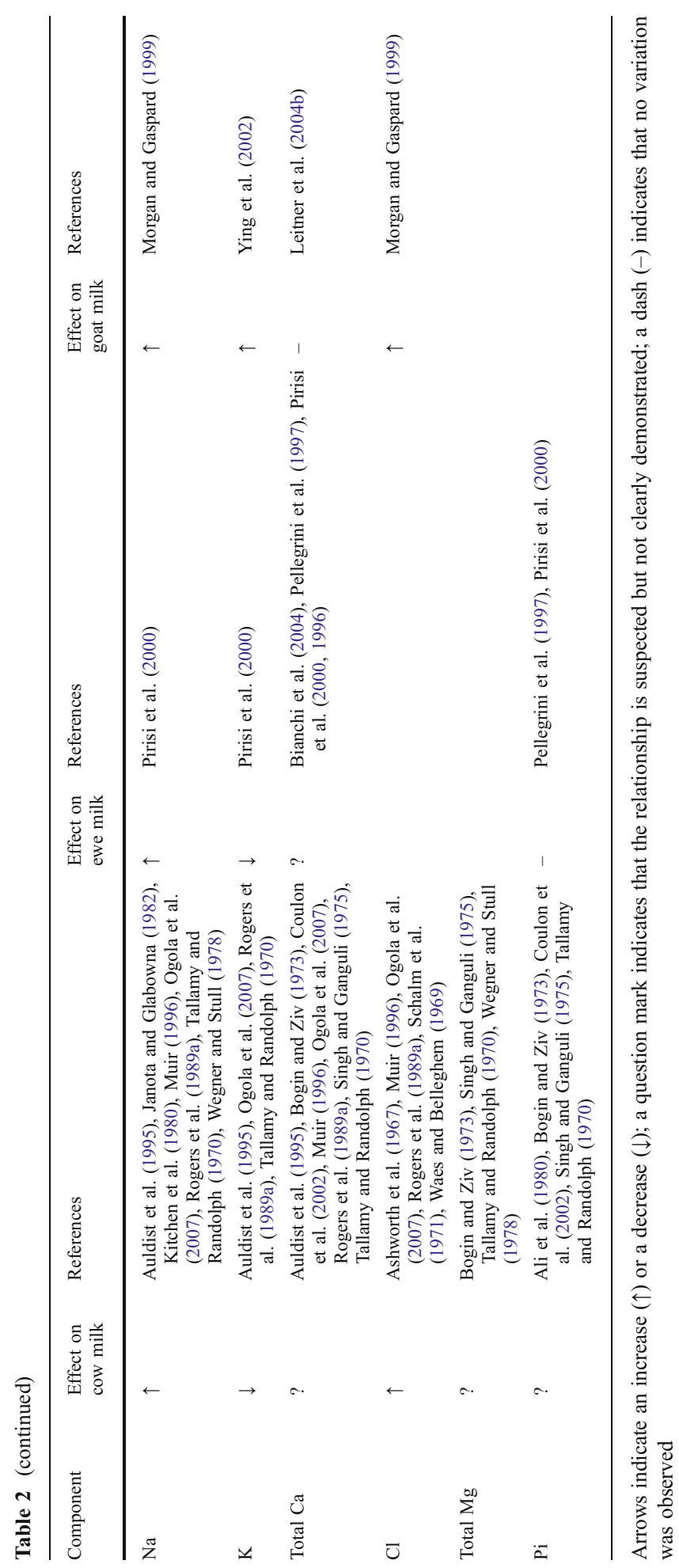


A decrease in fat concentration during mastitis can be expected due to a reduced synthetic and secretory capacity of the mammary gland (Auldist and Hubble 1998; Raynal-Ljutovac et al. 2007). However, results are unclear. A rise in free fatty acids has been reported in mastitic cows milk. This may be explained by the alteration of the milk fat globule membrane by leucocyte lipases or by plasmin through the hydrolysis of lipoproteins, both of which may enhance lipolysis. Nevertheless, results regarding lipoprotein lipase activity in mastitic milk are also contradictory: some authors found that its activity increased (Azzara and Dimick 1985b; Erwin and Randolph 1975; Randolph and Erwin 1974; Tallamy and Randolph 1970) during mastitis while others found that it decreased (Anderson 1982; Fitz-Gerald et al. 1981) or found no significant differences (Salih and Anderson 1979). Altogether these results appear somehow conflicting and it is difficult if not impossible to draw a clear conclusion upon the impact of high SCC on milk composition for most parameters. This can partly be explained by the sample methods used to study milk changes. Indeed, some studies are based on tank milk analysis, whereas others are based on milk pooled from the four quarters of one cow and others on single quarter milk. It can be hypothetized that analyses carried out on these different milk samples might indeed lead to variable results. However, it has been reported that changes in the bulk milk are similar to changes in the quarter milk (Le Roux et al. 2003). Many other criteria concerning ruminant management (genetic characteristics, physiological stage, and dietary factors) (Coulon et al. 2002; Raynal-Ljutovac et al. 2007) can be implicated. Finally, conflicting results can also be explained by the different pathogens involved in mastitis. As mentioned above, in most studies, the SCC is the sole marker considered to define mastitic milk and the causative agent is not sought and identified. Yet, mastitis symptoms and impacts on milk yield or composition might dramatically differ depending on the bacterial species involved in the onset of the disease.

Pathogen-specific changes in milk composition Among the pathogenic bacteria involved in mastitis, some induced changes in milk composition whereas others do not or barely affect milk composition. For example, $C$. bovis does not alter milk composition whereas milk modifications are more marked in the case of E. coli mastitis than in the case of mastitis induced by another pathogen (Coulon et al. 2002).

Each pathogen induces specific modification in milk during mastitis. For example, specific volatile metabolites detected in mastitis milk samples are formed by and are specific to each pathogen (Hettinga et al. 2009). Other components are more or less affected depending on the pathogen. S. uberis mastitis is typically associated with an increase in protein content, in casein, in calcium (Coulon et al. 2002) and in lactoferrin (Chaneton et al. 2008). On the contrary, Streptococcus dysgalactiae mastitis is associated with a significant increase in proteose peptone and plasmin, and no changes in fat, casein or protein content (Leitner et al. 2006; Merin et al. 2008). S. agalactiae mastitis is characterized by a decrease in specific milk proteins (caseins, $\alpha$-lactalbumin, and $\beta$-lactoglobulin).

The impact of $E$. coli mastitis on milk has been particularly studied, either under field conditions or in experimental infections (Fig. 1). During E. coli mastitis, lactoferrrin (whose concentration increases with the acuteness of coliform infections), protein content, proteose peptone and plasmin significantly increase 
whereas caseins, casein/protein ratio, calcium and phosphorus significantly decrease (Coulon et al. 2002; Kawai et al. 1999; Leitner et al. 2006; Michelutti et al. 1999). In E. coli mastitis, changes in whey proteins are rapidly observed and include a lower abundance of $\alpha$-S1 casein, $\beta$-casein, K-casein, $\alpha$-lactalbumin, and $\beta$-lactoglobulin, and a huge increase in bovine serum albumin. The presence of abundant proteins such as serotransferrin, fetuin ( $\alpha-2$-HS-glycoprotein), fibrinogen, and $\alpha$-1-acid glycoprotein, and minor proteins such as $\alpha$-1-antiproteinase, complement $\mathrm{C} 3$ and $\mathrm{C} 4$, TTR, proteinS100-A12, and several antimicrobial peptides (AMP) in the cathelicidin family have also been reported (Boehmer et al. 2008). Proportions of $\beta$ - and $\alpha$-caseins are significantly lower at $24 \mathrm{~h}(-49 \%)$ and between 48 and $72 \mathrm{~h}(-62 \%)$ respectively after $E$. coli injection (Michelutti et al. 1999).

Finally, S. aureus clinical mastitis is associated with a rise in lactoferrin, protein content, proteose peptone, plasmin and a decrease in casein/protein ratio, calcium, and phosphorus (Coulon et al. 2002; Hagiwara et al. 2003; Kawai et al. 1999; Leitner et al. 2006). Few changes are noticed during S. aureus subclinical mastitis which is only associated with a decrease in lactose content $\left(-2.1 \mathrm{~g} \mathrm{~kg}^{-1}\right)$ and casein/ protein ratio (-2\%) (Coulon et al. 2002) (Fig. 2). No difference between lactoferrin and SCC levels during chronic cows mastitis due to $S$. aureus or CNS have been reported (Komine et al. 2004).

As described in the first part, it is really difficult if not impossible to determine a global trend for changes in milk parameters linked to mastitis. For example, it has not been possible to determine whether there is an increase or a

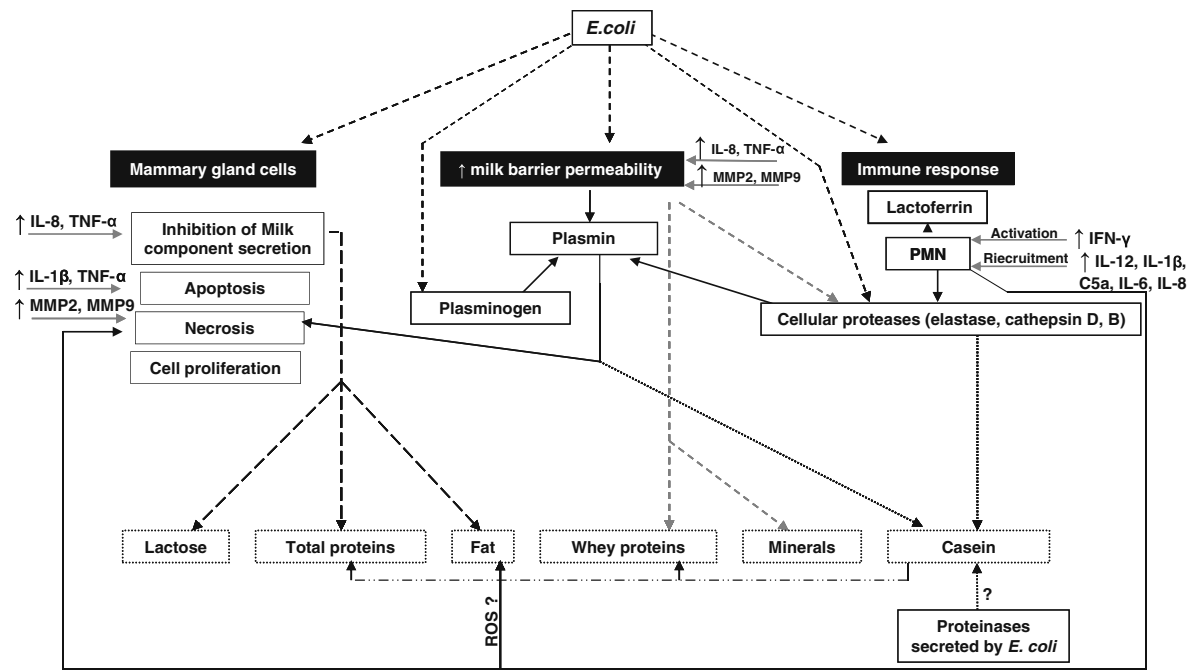

Fig. 1 Relationships between Escherichia coli intramammary infection, responses induced in the mammary gland and changes observed on milk components. Black arrows (dashed bold lines $\rightarrow \boldsymbol{}$ ) indicate a direct impact observed in infections with live E. coli; grey arrows (dashed bold lines $\| \mathrm{m} \rightarrow$ ) indicate a direct impact of experimental injection of E. coli lipopolysaccharide (LPS). All the other lines and arrows indicate a link reported in the literature (the various styles do not have any significance and are used for the readability of the figure). $P M N$ polymorphonuclear neutrophils, $M M P$ matrix metalloproteinases, ROS reactive oxygen species. Arrows indicate an increase (up) or a decrease (down). Question marks indicate that the relationship is suspected but not clearly demonstrated 


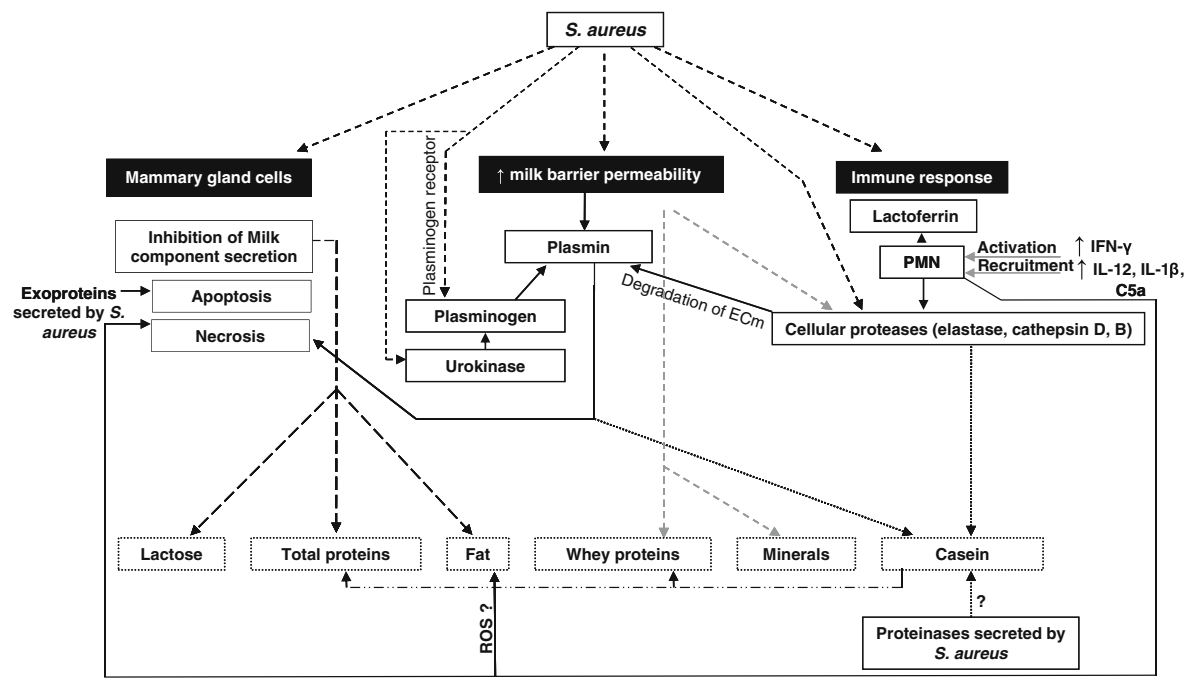

Fig. 2 Relationships between Staphylococcus aureus intramammary infection, responses induced in the mammary gland and changes observed on milk components. Black arrows (dashed bold lines-- $)$ indicate a direct impact observed in infections with live $S$. aureus. All the other lines and arrows indicate a link reported in the literature (the various styles do not have any signification and are used for the readability of the figure). $P M N$ polymorphonuclear neutrophils, $M M P$ matrix metalloproteinases, $R O S$ reactive oxygen species. Arrows indicate an increase (up) or a decrease (down). Question marks indicate that the relationship is suspected but not clearly demonstrated

decrease in calcium concentration in mastitic milk in comparison to normal milk. This may be explained by the fact that $S$. uberis mastitis is characterized by a rise in calcium whereas $E$. coli and $S$. aureus mastitis are characterized by a decrease in calcium. This demonstrates that determination of the pathogen involved in mastitis is crucial to understand the milk changes observed. The current scientific knowledge regarding, notably, the caracterisation of the impact of the pathogen presence on the mammary gland can partly explain why the impact on milk varies among pathogens.

\subsection{Impact of high SCC on dairy products}

A wide proportion of milk is transformed and besides the risks of bacterial contamination accompanying products based on raw milk, changes in the composition of mastitic milk can impair the transformation processes. Even when the composition of raw milk is hardly affected by mastitis, the quality of dairy products can deteriorate (Merin et al. 2008). The impacts of mastitis on dairy products, including pasteurized or UHT milks, cheeses and yogurts, are presented in the following paragraphs.

\subsubsection{Development of off-flavors in high SCC pasteurized and UHT milk}

Pasteurized or UHT milk made with high SCC milk are characterized by the developement of off-flavors which correspond to flavor or odor defects 
(rancidity, bitterness, oxidation, astringency, etc.). Three parameters can induce the development of off-flavors in pasteurized milk: development of bacteria in milk, proteolysis, and or lypolysis of milk components. The two latter phenomena do not necessarily rely on the development of bacteria and result from changes in endogenous enzymatic activities induced by the infection in mastitic milk. When the bacterial counts in raw milk are low (i.e., $<25,000 \mathrm{CFU} \cdot \mathrm{mL}^{-1}$ ), the only parameters that are likely to alter the milk flavor are the proteolysis and lipolysis of the milk components. At higher bacterial counts, the bacterial enzymatic activities might act synergistically with these phenomena to induce off-flavors (Barbano et al. 2006). Mastitic pasteurized or UHT milk is characterized by high levels of native proteases and lipases, mainly due to increased SCC and has been shown to be more susceptible to the development of off-flavors than pasteurized or UHT milk with a low SCC (Fernandes et al. 2008; Santos et al. 2003). For example, in high SCC pasteurized milk, the increase in free fatty acids (resulting from lipolysis) and casein hydrolysis were three and two times greater, respectively, than in low SCC pasteurized milk (Ma et al. 2000). Elevated levels of free fatty acids have been associated with rancidity (Ma et al. 2000; Shipe and Senyk 1981). Extensive proteolysis in milk can so result in the accumulation of small hydrophobic peptides, causing bitterness (Rouseff 1990) and astringency (Lemieux and Simard 1994). High SCC pasteurized milk has scored higher for bitterness and astringency or rancidity than low SCC milk (Ma et al. 2000; Rouseff 1990).

By increasing the SCC, mastitis can thus be responsible for the development of off-flavors in consumption milk, even after pasteurization or UHT treatment.

\subsubsection{Impact on yogurts}

The SCC has little impact on cows yogurt but can induce off-flavor development when exceeding 3,000,000 cells $\cdot \mathrm{mL}^{-1}$ in ewes yogurt (VivarQuintana et al. 2006). Regarding cows yogurts, the level of SCC does not seem to affect $\mathrm{pH}$ and titrable acidity, fat and protein content or microbiological characteristics (Fernandes et al. 2006; Oliveira et al. 2002). On the contrary, the $\mathrm{pH}$ of high SCC ewes yogurt decreased much faster (when SCC is above $3,000,000$ cells $\cdot \mathrm{mL}^{-1}$ ) during fermentation and was significantly lower after 15 days of storage (Vivar-Quintana et al. 2006). The use of high SCC milk in the manufacture of yogurt seems to reduce the storage period and shelf life of the product. The use of cows milk containing less than 400,000 cells $\cdot \mathrm{mL}^{-1}$ allowed the yogurt to be stored for 30 days without organoleptic changes being detected. On the contrary, high SCC cows yogurt have been characterized by a loss of consistency after 20 days of storage at $5{ }^{\circ} \mathrm{C}$ and a decrease in taste after 30 days of storage at $5{ }^{\circ} \mathrm{C}$ (Oliveira et al. 2002). In the same way, the viscosity of yogurts made with high SCC milk increased during storage whereas no evolution was observed for yogurts made with low SCC milk (Fernandes et al. 2006). It is worth noting that only a few problems have been associated with cows high SCC yogurt (Fernandes et al. 2006; Oliveira et al. 2002; Rogers and Mitchell 1994; Schott 1967) whereas ewes high SCC yogurts have been associated with a bitter and piquant taste (Vivar-Quintana et al. 2006). Beside the impact on taste and shelflife, 
no correlation between the appearance and aroma and SCC level has been observed (Oliveira et al. 2002).

\subsubsection{Impact on cheeses}

Cheese production represents a major use of milk especially regarding ewes and goats milk which are mostly dedicated to cheese production. Studies on the impact of SCC on the cheesemaking process or quality are however scarce and the impact of high SCC on cheese properties has not yet been clearly determined. The impact appears to vary among cheese types but in summary, the use of high SCC milk seems to impair coagulation properties, to increase moisture content in most cows cheeses and induce off-flavor development. The impact of high SCC on the cheesemaking process and cheese properties are discussed in the following sections and summarized in Table 3.

Coagulation properties Although some studies have reported no effect of high SCC $\left(>500,000\right.$ cells $\left.\cdot \mathrm{mL}^{-1}\right)$ milk on rennet coagulation properties, in most studies, a high SCC is associated with a significant increase in rennet clotting time, with a lower curd firmness and a slower rate of curd firming, which can lead to poor yield and low quality of the resultant cheese. There is a high positive correlation between $\mathrm{pH}$ and coagulation properties (Raynal-Ljutovac et al. 2007). The rise in $\mathrm{pH}$ observed in high SCC milk can be partly responsible for the coagulating problems observed with mastitic milk.

Of note, casein concentration in milk affects the renneting behaviour of milk. Peptides which are liberated from caseins during the proteolysis of milk seem to have a negative effect on the clotting time and the curd firmness. For example, proteose peptones, casein derivates, have been shown to be involved in issues with the curd formation. Casein proteolysis and the subsequent liberation of peptides may explain part of the rennet coagulation issues. Moreover, starter activity and growth are reduced in mastitic milk. High SCC $\left(>400,000\right.$ cells $\left.\cdot \mathrm{mL}^{-1}\right)$ milk prolonged the fermentation process by as much as 2 to $4 \mathrm{~h}$. Acid producing microorganisms (i.e., starter LAB) are more affected by the antimicrobial components produced during mastitis than aroma-producing microorganisms (nonstarter LAB and ripening flora). The effect of high SCC might nevertheless depend on the LAB species considered as the acidifying activity of Streptococcus thermophilus is increased while that of Lactobacillus acidophilus is inhibited.

From a microbial perspective, the impact of some mastitic pathogens has been clearly shown to negatively affect coagulation. For example, $S$. dysgalactiae has such a huge impact on milk composition that no curd has been produced from infected milk in experimental cheesemaking. S. dysgalactiae infection results in reduced yields in both cheese and yogurt production. S. dysgalactiae directly generates (through its enzymatic activities) or activates the formation of short-chain peptides, which interfere with the coagulation process. Clotting time has also been shown to be significantly higher in $S$. aureus mastitic milk than in normal milk and curd firmness slightly decreased. Altogether these data show that most mastitis pathogens directly or indirectly affect milk coagulation by impacting either rennet or starter activity. 
Table 3 Effect of high SCC milk on cheese characteristics

\begin{tabular}{|c|c|c|c|}
\hline Ruminant & Type of cheese & Effect of mastitis & Reference \\
\hline \multirow[t]{5}{*}{ Cow } & Swiss-type cheese & $\begin{array}{l}\text { Protein content } \downarrow \text { and } \mathrm{pH}- \\
\text { Fat content } \uparrow \text { and protein whey } \uparrow\end{array}$ & Cooney et al. (2000) \\
\hline & Cheddar & $\begin{array}{l}\text { Protein content } \downarrow \text {, fat content } \downarrow \text {, casein } \\
\text { content } \downarrow \text {, cheese yield } \downarrow \text {, texture } \downarrow \text {, and } \\
\text { flavor } \downarrow \\
\text { Moisture } \uparrow\end{array}$ & $\begin{array}{l}\text { Ali et al. (1980), Auldist et al. } \\
\text { (1996), Barbano et al. (1991), } \\
\text { Donelly and Barry (1983), } \\
\text { Grandison and Ford (1986), } \\
\text { Leavitt et al. (1982), Marino et } \\
\text { al. (2005), Mitchell et al. } \\
\text { (1986), Munro et al. (1984), } \\
\text { Politis and Ng-Kwai-Hang } \\
\text { (1988a), Rogers and Mitchell } \\
\text { (1994), Verdi et al. (1987) }\end{array}$ \\
\hline & Cottage cheese & $\begin{array}{l}\text { Protein content } \downarrow \text { and cheese yield } \downarrow \\
\text { Moisture } \uparrow\end{array}$ & Vianna et al. (2008) \\
\hline & Pratto cheese & $\begin{array}{l}\text { Protein content }- \text { and fat content }- \\
\text { Moisture } \uparrow \text {, clotting time } \uparrow \text { and } \mathrm{pH} \uparrow \\
\text { Texture } \downarrow \text { and flavor } \downarrow\end{array}$ & $\begin{array}{l}\text { Mazal et al. (2007), Vianna et al. } \\
\text { (2008) }\end{array}$ \\
\hline & Mozzarella cheese & $\begin{array}{l}\text { Yield }- \text { and physical parameters - } \\
\text { Protein content } \downarrow \text { and casein content } \downarrow \\
\text { Free fatty acids } \uparrow\end{array}$ & Andreatta et al. (2007) \\
\hline \multirow[t]{3}{*}{ Ewe } & $\begin{array}{l}\text { Zamorano-type } \\
\text { cheese }\end{array}$ & $\begin{array}{l}\text { Yield }- \text {, moisture }- \text {, and firmness - } \\
\text { Hardness, cohesiveness } \downarrow \text {, and flavor } \downarrow \\
\text { Grainy } \uparrow \text {, crumbly, adhesiveness } \uparrow \text {, } \\
\quad \text { guminess, and chewiness }\end{array}$ & Revilla et al. $(2007,2009)$ \\
\hline & Manchego type & $\begin{array}{l}\text { Total protein } \downarrow \text {, casein } \downarrow \text {, and fat content } \downarrow \\
\text { Free fatty acid } \uparrow \text {, moisture } \uparrow \text {, clotting time } \\
\quad \uparrow \text {, rancidity } \uparrow \text {, crumbly, and mealy } \\
\text { texture } \uparrow\end{array}$ & Jaeggi et al. (2003) \\
\hline & $\begin{array}{l}\text { Canestrato pugliese } \\
\text { cheese }\end{array}$ & $\begin{array}{l}\text { Moisture } \uparrow \\
\text { Fat content } \downarrow \\
\text { Proteose peptone - }\end{array}$ & Albenzio et al. (2004) \\
\hline Goat & $\begin{array}{l}\text { Soft ripened goat } \\
\text { cheese }\end{array}$ & - & $\begin{array}{l}\text { Morgan and Gaspard (1999), } \\
\text { Zeng and Escobar (1996) }\end{array}$ \\
\hline
\end{tabular}

Arrows indicate an increase $(\uparrow)$ or a decrease $(\downarrow)$; a dash $(-)$ indicates that no variation was observed

By affecting the renneting step, high SCC reduces the production yields of some cheeses, e.g., cottage cheese, cheddar, whereas it does not affect the yield of Prato cheese, mozzarella, or zamorano.

On the contrary, concerning goats cheese yield, studies have clearly shown that high SCC has no impact.

Moisture content Moisture content is generally increased in cows cheese made from high SCC milk. This was observed in dramatically different cheese types including cheddar, cottage, and Prato cheeses. The mechanism by which SCC influences cheese moisture has not yet been clearly determined. Goats cheese made with high 
electrical conductivity milk, which corresponds to cheese made with mastitic milk, is also associated with higher moisture content in comparison to cheese made with milk from healthy goats (Romero et al. 2010).

Moisture content of fresh ewes milk increases with SCC but the difference does not seem to be significant after 3 months of ripening between cheeses made with low or high SCC.

Impact of mastitis on cheese composition Higher levels of proteolysis have been observed in cheeses made with high SCC regardless the cheese type. This has been observed in Swiss-type cheeses, cottage cheese, cheddar, Prato cheese, and mozzarella. Mastitic milk influences primary proteolysis of caseins which results in the increased proteolysis of $\beta$-caseins during the early stages of cheese ripening. Moreover, it induces an accelerated breakdown of $\alpha_{\mathrm{S} 1}$-casein. As a consequence, protein losses in the whey is increased.

Fat losses in the whey also increase whereas fat content in cheese decreases except in Prato cheese.

Mastitis can induce the production off-flavors and texture defects The use of high SCC milk also negatively impacts on flavor, body and texture grades. For example, cheddar cheeses made with high SCC milk have been described as having a "lipolytic" or "oxidized" flavor and the milk used to prepare these cheeses had a higher concentration of free fatty acids, which can induce rancidity in dairy products (Auldist et al. 1996). Flavor or texture defects have also been reported for mozzarella, Prato or ewes cheeses made with high SCC milk. This was explained by higher levels of lipolysis or proteolysis in the cheese (Andreatta et al. 2007).

Sensory characterictics of goats soft cheeses do not seem to be affected by high SCC (Chen et al. 2010; Morgan and Gaspard 1999; Zeng and Escobar 1996). Technological factors, notably the short ripening time in comparison with semi-hard cows or ewes cheese, may explain the minor influence of SCC on texture and flavors of goats soft cheeses (Raynal-Ljutovac et al. 2007). Indeed, it has been shown that high SCC $\left(1,000,000\right.$ cells $\cdot \mathrm{mL}^{-1}<\mathrm{SCC}<1,500,000$ cells $\cdot \mathrm{mL}^{-1}$ ) in goats milk also affects the sensory quality of aged cheeses (Chen et al. 2010).

Published literature has clearly shown that mastitis is a major problem in the transformation of milk mainly because of a lower acceptance by the consumer due to flavor and texture defects. Moreover, dairy products made from mastitic milk seem to have a shorter storage time compared with dairy products made from normal milk and always develop off-flavors especially in ewes and cows milk cheeses.

In most of the studies presented here concerning both milk and dairy products, the pathogen responsible for mastitis was not identified. As described in the first part, reported data regarding many of the milk components are conflicting. This could be explained by the very different impact of the causative microbial agents on milk and on the mammary gland immune response and so on the milk composition. Except for cheddar, studies on the impact of mastitis on cheeses are scarce and the impact of the different causative agents should be tested. We will indeed see hereafter that the 
impacts of mastitis on the mammary gland and subsequently on milk changes vary with the causative agents.

\section{How do bacteria induce various milk changes?}

Changes in milk composition due to mastitis can be explained by the physical damage of the mammary tissue, which reduces the synthesis and secretory function of the mammary gland (Kitchen 1981). Gene expression profile of mammary cells is modified in incidences of mastitis. Notably, genes encoding antimicrobial proteins are induced. Mastitis also induces a rise in endothelium permeability which increases the passage of components from the blood to the milk and the activity of endogenous and exogenous enzymes that destroy some milk components. Among the causative agents of cows mastitis, $S$. aureus is the most prevalent bacterium involved in contagious mastitis, with $E$. coli and $S$. uberis being the main environmental pathogens (Chaneton et al. 2008). These species are also the most studied among bacteria involved in mastitis. In small ruminants, $S$. aureus is the main agent implied in clinical mastitis and CNS in subclinical mastitis (Bergonier et al. 2003).

The aim of this part is to present up to date knowledge about the role played by the main bacterial species implicated in mastitis and how they affect the composition of milk and dairy products. In light of these data, it is possible to compare how these mastitis causative agents differentially affect milk quality.

\subsection{Direct impact of bacteria on milk composition?}

E coli appear to be capable of degrading caseins in vitro (Haddadi et al. 2005). Casein proteolysis is greater in an E. coli experimental infection compared with LPS induced mastitis (Moussaoui et al. 2002; Moussaoui et al. 2004). This observation seems to be related to a direct or indirect role of $E$. coli in casein proteolysis. The in vitro activity of four proteases of the $E$. coli strain P4 on caseins was very low. To explain caseinolysis, the authors hypothesized that these proteases are produced at a higher level in vivo or that they posess a higher caseinolytic activity. Alternatively, E. coli might have an indirect role on caseinolysis by increasing the secretion of endogenous proteases or factors acting on the maturation of somatic cells (Dufour et al. 2009). The mechanisms involved in caseinolysis observed during E. coli mastitis remain to be further determined (Fig. 1).

$S$. aureus also produces proteases (serine protease, cysteine proteases, metalloprotease) that are capable of degrading caseins (Karlsson and Arvidson 2002). For example, SplB and SplC can degrade casein (Reed et al. 2001). CNS also produce proteases (Devriese et al. 1985; Miedzobrodzki et al. 1989; Zhang and Maddox 2000). But as for E. coli, no proof has so far clearly demonstrated that $S$. aureus or CNS produce in vivo enzymes implied in caseinolysis.

\subsection{Impact of the immune response on milk changes}

Humoral and cellular defenses of the mammary gland in response to infection affect milk composition or milk product quality. 


\subsubsection{Humoral defenses}

The complement system, lactoferrin, transferrin, lysosyme, lactoperoxidasethiocyanate-peroxide-system, xanthine oxydase, antibodies are components of the humoral defenses (Rainard and Riollet 2006). They are present in normal milk but increase during mastitis (Carlsson et al. 1989; Hiss et al. 2008; Schmedt Auf Der Gunne et al. 2002; Seifu et al. 2005). Some of these immune response components can be the source of problems related to milk product manufacturing. For example, the presence of immunoglobulins in milk induces the formation of agglutins, which can inhibit acid production in raw and pasteurized whole or skim milk. This has been shown to cause problems in the manufacture of cottage cheese (Salih and Sandine 1984) but not in the manufacture of hard cheeses. During cottage cheese manufacture, lactic streptococcal agglutinins can cause the starter bacteria to separate from the milk components or result in the uneven distribution of lactic acid production in the milk (Emmons et al. 1963; Emmons et al. 1966; Lucas 1962; Salih and Sandine 1980). On the contrary, during the manufacture of hard cheese, the rennet coagulum immobilizes the bacteria in the curd and prevents their migration to the surface. However, the selection of strains which are resistant to agglutination for the manufacture of cottage cheese can overcome this problem.

The lactoperoxidase system can also inhibit the activity of starter cultures. But, as for agglutins, a screening of starter bacteria for resistance to the lactoperoxidase system can overcome the problem (Seifu et al. 2003). Nevertheless, this can change yogurt properties due to alterations in the formation of the gel network (Ozer et al. 2003) and the texture which is softer and smoother in yogurt made with milk with high lactoperoxidase level (Hirano et al. 1998). It can also induce the oxidation of proteins in milk (Ostdal et al. 2000).

Contrary to agglutins and lactoperoxidase, lysosyme does not seem to induce problems in the manufacture of milk products. Observations of lactic acid bacteria (LAB) challenged by lysozyme during the production of Grana Padano (Grazia et al. 1984; Neviani et al. 1996; Ottogalli et al. 1983) or Gouda (Bester and Lombard 1990) cheeses have shown that the functionality of the LAB population is not impeded. Most of Lactobacillus sp. and S. thermophilus possess a natural resistance to lysozyme or have developed a resistance by repeated exposure (Neviani et al. 1996; Ottogalli et al. 1983). Trials with goats milk have also demonstrated that the presence of lysosyme throughout the cheesemaking process is not detrimental to production (Scharfen et al. 2007).

Methods used to measure the concentration or activity of some milk components (e.g., lactoferrin and lactoperoxydase system) are more or less sensitive, especially when comparing ruminant species. For example, ELISA kits used for the measurement of bovine lactoferrin do not work on goats milk (Hodgkinson et al. 2008) and false-positive results have often been obtained not only for lactoferrin but also for the lactoperoxidase system (Raynal-Ljutovac et al. 2005). To overcome this problem, techniques used to measure lactoferrin have been adapted at least to goats milk (Chen et al. 2004; Hodgkinson et al. 2008).

Few data are available regarding the impact of each pathogen on the increase in the components of humoral defenses. Among the three main mastitis agents, $S$. uberis, E. coli, and S. aureus, all of which induce an increase in the lactoferrin 
content in milk, $S$. uberis induces the greatest increase but is also the most resistant to lactoferrin activity (Carlsson et al. 1989). Finally, as reported here, solutions have been found to solve most of the manufacturing troubles encountered with components of humoral defenses.

\subsubsection{Cellular defenses}

As reported above, the increase in the SCC varies according to the pathogen and/or to the mastitis type and symptoms. Besides the variations in the SCC levels in response to pathogens, cytokine profiles can also be different. Several cytokines (IFN- $\gamma$, interleukin (IL)-6, IL-10, IL-12, and C5a) are commonly induced by E. coli, S. aureus, and $S$. uberis, as shown in Table 4. Nevertheless, some differences are observed, notably concerning the time of cytokine induction. For example, in experimentally induced mastitis by Staphylococcus epidermidis (CNS) in ewe, a permanent increase in the level of IL-8 (even 10 weeks after infection) and a transient increase in the level of IL$1 \beta$ have been reported (Winter et al. 2003).

Each cytokine will have consequences on the milk barrier permeability, on the gene expression profile, or on the polymorphonuclear leukocytes (PMN) recruitment. Their implication in the mechanisms of milk modification is further described in the following sections.

The main consequences of the presence of pathogens are the recruitment of leucocytes, notably PMN, the synthesis of antimicrobial peptides or proteins by cells from the mammary gland and the release of cytokines. This will induce consequences on the properties of milk and milk products.

Release of leucocyte proteinases induces casein proteolysis As discussed in previous paragraphs, the presence of a pathogen results in an increase in the SCC, notably in PMN. The level or activity of leucocyte proteases (listed in Table 5) also increases during mastitis (Barbano et al. 1991). The origin of this increase in proteases during mastitis is linked to an increase in PMN and could be explained by two mechanisms: the proteases can be released by vesicules like lysosomes from PMN or caseins or fat globules can be endocytised by PMN with the degradation products being released into the milk after intracellular digestion (Le Roux et al. 2003).

The order in which caseins are degraded by leucocyte proteinases are firstly $\alpha_{\mathrm{S}_{1}}$ casein, followed by $\beta$-casein and to a lesser extent $\mathrm{K}$-casein (Grieve and Kitchen

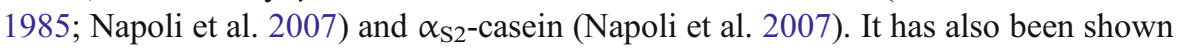

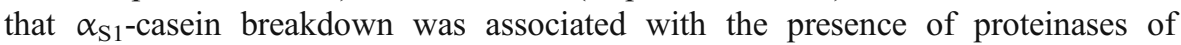
somatic cells with high SCC (Verdi et al. 1987).

\section{Elastase}

Elastase is a serine protease that digests a wide variety of protein substrates (Brink et al. 1956). It lyses bovine $\beta$ - (Considine et al. 1999) and $\alpha_{\mathrm{S} 1}$-caseins (Considine et al. 2000). An increased activity of elastase is detected during mastitis in PMN (Haddadi et al. 2006; Prin-Mathieu et al. 2002). Peptides present in milk are linked to elastase activity (Wedholm et al. 2008) and certain fragments in high SCC milk have been ascribed to elastase activity (Moussaoui et al. 2003; Nabhan et al. 2004). Elastase contributes to increased proteolysis in 
Table 4 Inflammatory mediators' variation during Staphylococcus aureus, Escherichia coli, and Streptococcus uberis mastitis

\begin{tabular}{|c|c|c|}
\hline Pathogen & $\begin{array}{l}\text { Inflammatory } \\
\text { mediators }\end{array}$ & Reference \\
\hline \multirow[t]{11}{*}{ E. coli } & IFN- $\gamma$ & Bannerman (2009), Lee et al. (2006) \\
\hline & IL- $1 \beta \uparrow$ & Bannerman et al. (2004b), Riollet et al. (2000), Shuster et al. $(1995,1997,1996)$ \\
\hline & IL-6 $\uparrow$ & $\begin{array}{l}\text { Hagiwara et al. (2001), Nakajima et al. (1997), Ohtsuka et al. (2001), Shuster et } \\
\text { al. (1997) }\end{array}$ \\
\hline & IL-8 $\uparrow$ & $\begin{array}{l}\text { Bannerman et al. (2004b), Lee et al. (2003), Riollet et al. (2000), Vangroenweghe } \\
\text { et al. }(2005,2004)\end{array}$ \\
\hline & $\mathrm{IL}-10 \uparrow$ & Bannerman et al. (2004b) \\
\hline & IL-12 $\uparrow$ & Lee et al. (2006) \\
\hline & TGF- $\alpha \uparrow$ & Chockalingam et al. (2005, Sheffield 1997) \\
\hline & TGF- $\beta \uparrow$ & Chockalingam et al. (2005) \\
\hline & $\mathrm{TNF}-\alpha \uparrow$ & $\begin{array}{l}\text { Bannerman et al. (2004b), Lee et al. (2003), Riollet et al. (2000), Shuster et al. } \\
(1995,1997,1996)\end{array}$ \\
\hline & LBP $\uparrow$ & Bannerman et al. (2004b) \\
\hline & $\mathrm{C} 5 \mathrm{a} \uparrow$ & $\begin{array}{l}\text { Bannerman et al. (2004b), Riollet et al. (2000), Shuster et al. (1997), } \\
\text { Vangroenweghe et al. (2004) }\end{array}$ \\
\hline \multirow[t]{15}{*}{ S. aureus } & IFN- $\gamma \uparrow$ & Bannerman (2009), Riollet et al. (2000) \\
\hline & IL-1 $\beta$ ? & Bannerman (2009), Griesbeck-Zilch et al. (2008), Riollet et al. (2000) \\
\hline & IL-6 $\uparrow$ & $\begin{array}{l}\text { Griesbeck-Zilch et al. (2008), Hagiwara et al. (2001), Nakajima et al. (1997), } \\
\text { Ohtsuka et al. (2001), Shuster et al. (1997) }\end{array}$ \\
\hline & IL-8 ? & $\begin{array}{l}\text { (Bannerman 2009; Griesbeck-Zilch et al. 2008; Lee et al. 2006; Riollet et al. } \\
\text { 2000; Tao and Mallard 2007) }\end{array}$ \\
\hline & IL-10 $\uparrow$ & Bannerman et al. (2004b) \\
\hline & IL-12 $\uparrow$ & Alluwaimi et al. (2003), Lee et al. (2006) \\
\hline & $\mathrm{TGF}-\alpha \uparrow$ & Bannerman et al. (2006), Sheffield (1997) \\
\hline & TGF- $\beta \uparrow$ & Bannerman et al. (2006) \\
\hline & TNF- $\alpha$ protein - & Bannerman et al. (2004a), Riollet et al. (2000) \\
\hline & TNF- $\alpha$ RNA $\uparrow$ & Bannerman et al. (2004a), Griesbeck-Zilch et al. (2008), Lutzow et al. (2008) \\
\hline & $\mathrm{LBP} \uparrow$ & Bannerman et al. (2004a) \\
\hline & $\mathrm{C} 5 \mathrm{a} \uparrow$ & Bannerman et al. (2004a), Riollet et al. (2000) \\
\hline & IL-15 $\uparrow$ & Tao and Mallard (2007) \\
\hline & IL-17 $\uparrow$ & Tao and Mallard (2007) \\
\hline & IL-18 个 & Tao and Mallard (2007) \\
\hline \multirow[t]{8}{*}{ S. uberis } & IFN- $\gamma \uparrow$ & Bannerman (2009), Swanson et al. (2009) \\
\hline & IL- $1 \beta \uparrow$ & Bannerman et al. (2004a), Rambeaud et al. (2003), Swanson et al. (2009) \\
\hline & IL-6 $\uparrow$ & Swanson et al. (2009) \\
\hline & IL-8 ? & Bannerman et al. (2004a), Rambeaud et al. (2003), Swanson et al. (2009) \\
\hline & $\mathrm{IL}-10 \uparrow$ & Bannerman et al. (2004a), Swanson et al. (2009) \\
\hline & IL-12 $\uparrow$ & Bannerman et al. (2004a) \\
\hline & $\mathrm{TNF}-\alpha \uparrow$ & Bannerman et al. (2004a), Rambeaud et al. (2003), Swanson et al. (2009) \\
\hline & $\mathrm{C} 5 \mathrm{a} \uparrow$ & Bannerman et al. (2004a) \\
\hline
\end{tabular}

Arrows indicate an increase $(\uparrow)$ or a decrease $(\downarrow)$; a question mark indicates that the relationship is suspected but not clearly demonstrated; a dash $(-)$ indicates that no variation was observed 
Table 5 List of endogenous proteases involved in casein lysis

\begin{tabular}{|c|c|c|c|c|}
\hline Protease & Origin & Type & Substrate & Reference \\
\hline Plasmin & $\begin{array}{l}\text { Milk-blood } \\
\text { during mastitis? }\end{array}$ & Serine protease & $\begin{array}{r}\beta-, \alpha_{\mathrm{S} 2^{-}}, \text {and } \\
\alpha_{\mathrm{S} 1^{-}} \text {caseins }\end{array}$ & $\begin{array}{l}\text { Bastian and Brown } \\
\text { (1996), Fox and } \\
\text { McSweeney (1996) }\end{array}$ \\
\hline Cathepsin D & $\begin{array}{l}\text { Leucocyte } \\
\text { proteinase }\end{array}$ & Aspartyl protease & $\begin{array}{l}\alpha_{\mathrm{S} 1^{-}} \text {and } \beta \text {-caseins } \\
\quad\left(\kappa-\text { and } \alpha_{\mathrm{S} 2} \text {-caseins }\right)\end{array}$ & $\begin{array}{l}\text { Grieve and Kitchen } \\
\text { (1985), Napoli et } \\
\text { al. (2007) }\end{array}$ \\
\hline Cathepsin G & $\begin{array}{l}\text { Leucocyte } \\
\text { proteinase }\end{array}$ & Neutral serine protease & $\begin{array}{l}\beta \text { - and } \alpha_{\mathrm{S} 1} \text {-caseins } \\
\quad\left(\mathrm{K} \text {-and } \alpha_{\mathrm{S} 2} \text {-caseins }\right)\end{array}$ & $\begin{array}{l}\text { Considine et al. } \\
\text { (2002a) }\end{array}$ \\
\hline Cathepsin B & $\begin{array}{l}\text { Leucocyte } \\
\text { proteinase }\end{array}$ & Cysteine protease & $\begin{array}{l}\beta-\text { and } \alpha_{\mathrm{S} 1} \text {-caseins } \\
\quad\left(\kappa-\text { and } \alpha_{\mathrm{S} 2} \text {-caseins }\right)\end{array}$ & $\begin{array}{l}\text { Considine et al. } \\
\text { (2004) }\end{array}$ \\
\hline Elastase & $\begin{array}{l}\text { Leucocyte } \\
\text { proteinase }\end{array}$ & Serine protease & $\begin{array}{l}\beta \text { - and } \alpha_{\mathrm{S} 1} \text {-caseins } \\
\quad\left(\mathrm{K} \text {-and } \alpha_{\mathrm{S} 2} \text {-caseins }\right)\end{array}$ & $\begin{array}{l}\text { Considine et al. } \\
\quad(1999,2000)\end{array}$ \\
\hline
\end{tabular}

milk with an SCC above 500,000 cells $\cdot \mathrm{mL}^{-1}$ (Wedholm et al. 2008). It also influences the rheology of rennet gels and may influence the coagulation properties of milk (Considine et al. 2002b), which could partly explain changes observed in coagulation of high SCC milk.

Cathepsins D, G, and B

Cathepsin $G$ is a neutral serine proteinase that displays specificity on $\beta$ - and $\alpha_{\mathrm{S} 1}$-caseins (Considine et al. 2002a). Therefore, it is possible that indigenous cathepsin $G$ in milk may be present at significant levels to impact on the proteolysis of milk proteins.

Cathepsin B and D have been shown to be involved in the proteolysis of high SCC milk (Wedholm et al. 2008). Cathepsin B is a cysteine proteinase that can partially resist heat treatments such as conventional pasteurization. It was shown to be capable of cleaveing $\beta$ - and $\alpha_{\mathrm{S} 1}$-caseins (Considine et al. 2004) and hence is involved in milk proteolysis. A correlation between cysteine proteinase and SCC has previously been shown (Larsen et al. 2004; O'Driscoll et al. 1999; Somers et al. 2003; Suzuki and Katoh 1990). Cathepsin B also seems to be involved in proteolysis during cheddar cheese ripening (Marino et al. 2005) and peptides derived from its activity have been detected in high SCC milk (Wedholm et al. 2008). Finally, similar to elastase, cathepsin B has been shown to affect the rheology of rennet gels and to influence the coagulation properties of milk (Considine et al. 2002b).

Cathepsin D is a lysosomal enzyme (Kelly et al. 2006) and is regarded as a macrophage proteinase. It hydrolyses the four types of caseins and is capable of catalysing milk coagulation (Kaminogawa et al. 1980; Larsen et al. 1996; McSweeney et al. 1995), which may explain the presence of clots in mastitic milk (Kelly et al. 2006). Its level has been positively correlated with SCC (Larsen et al. 2006; O'Driscoll et al. 1999; Somers et al. 2003). Procathepsin D, the proenzyme of cathepsin D, and cathepsin appear to have remained partially active after commercial pasteurization processes (Larsen et al. 2000). Increasing evidence has indicated a role for this enzyme in proteolysis in cheese during ripening (Marino et al. 2005), especially in cheese where rennet activity is low, such as Swiss 
cheese, Quarg, and Feta (Hurley et al. 2000; Larsen et al. 2000). The activity of cathepsin D is higher in milk with a high SCC than in milk with a low SCC and contributes to the proteolysis observed in S. uberis mastitic milk (Larsen et al. 2004). Moreover, peptides derived from cathepsin D activity have been identified in high SCC milk (Wedholm et al. 2008) and extensive hydrolysis of $\alpha_{\mathrm{S} 1 \text {-casein }}$ in high SCC milk seems to be related to cathepsin D activity (Somers et al. 2003). Link between pathogen and PMN proteases?

No data is available regarding the role of each pathogenic bacterium on leucocyte protease release or activity. This has only been studied in E. coli mastitis, where the level or activity of endogenous proteases increases and may explain caseinolysis (Moussaoui et al. 2002). But as shown earlier, the increase in the SCC varies dramatically depending on the pathogen. Thus, it could be hypothetized that the release of proteases increases with SCC and may vary depending on the pathogen. Moreover the activity of elastase and cathepsin G, the predominant proteases produced by somatic cells during mastitis (Azzara and Dimick 1985b) is promoted by pro-inflammatory cytokines at a transcriptional level (Haddadi et al. 2006; Le Roux et al. 2003): IL-1 and IL-8 for collagenase IV (Opdenakker et al. 2001) and IL-6, IL-2, tumor necrosis factor alpha (TNF- $\alpha$ ) for elastase, or cathepsin G (Bank and Ansorge 2001). The cytokine profile appears to be pathogen specific which suggests that it may differentially impact on protease gene transcription.

The mechanism involved in how PMN proteases can lyse caseins has yet to be determined. Moreover up to now, no study has compared the impact of pathogen species on this phenomenon. The specific increase in SCC and cytokine specific profiles suggest that it may be different depending on the pathogen but this still has to be demonstrated.

Release of other enzymes Several indigenous enzymes increase during inflammation, notably there is an exponential increase in enzymes originating from phagocytes $(N$ acetyl-D-glucosaminidase, beta-glucuronidase, and catalase) (Pyörälä 2003). They are released into milk from neutrophils during phagocytosis and cell lysis, and to some degree, damage epithelial cells (Kitchen et al. 1984).

It could be hypothesized that phagocytes also release lipases. A high level of lipolysis is actually associated with a high level of PMN but the mechanism by which PMN affect fat lipolysis remains to be determined (Gargouri et al. 2008). Milk SCC are suspected to be involved in the lipolysis of the fat globule triglycerides and thus in off-flavor development due to free fatty acids (Azzara and Dimick 1985a; Gargouri et al. 2008; Ma et al. 2000; Murphy et al. 1989; Santos et al. 2003). Moreover, lipases can resist pasteurization (Ma et al. 2000; Shipe and Senyk 1981) and high SCC pasteurized dairy products are thus more likely to develop off-flavors than low SCC ones.

\subsection{Increased endothelial permeability}

Mastitis is characterized by an increase in milk barrier permeability. In the presence of a pathogen, macrophages release IL- 8 and TNF- $\alpha$, which results in PMN recruitment from 
blood to milk (Watanabe et al. 2008; Lehtolainen et al. 2004; Shuster et al. 1996; Watanabe et al. 2000). This requires an increase in endothelial permeability, which induces not only the transfer of PMN from blood to milk but also other blood components such as bovine serum albumin (BSA). Lipolysis in milk can be explained by the disturbance of the milk-blood barrier which allows the transfer of esterases from blood to mastitic milk (Hettinga et al. 2009). Another example of increased permeability is found in transferrin (an iron transporter), which is not produced in the mammary gland of ruminant (Sanchez et al. 1992) but comes from blood serum (OllivierBousquet 1998) and rapidly increases in E. coli mastitis (Rainard and Caffin 1983) .

Indigenous proteases can degrade the extracellular matrix and are involved in the impairment of the milk barrier permeability. Elastase and cathepsin G degrade fibronectin, thrombospondin, and von Willerbrand factor (Bonnefoy and Legrand 2000). BSA concentration varies significantly according to the pathogen (Coulon et al. 2002). If the BSA content is considered as a marker of the impairment of the blood barrier, it could then be concluded that the permeability of the blood barrier increases by a different mechanism depending on the pathogen. BSA content in E. coli mastitic milk is significantly higher than in $S$. aureus mastitic milk, which is itself significantly higher than in S. uberis mastitic milk (Coulon et al. 2002).

\subsection{Inhibition of milk component production}

Mastitis is characterized by a decrease of and changes in milk components, which is illustrated by a decrease in lactose. Loss in milk yield can be attributed to the loss of mammary epithelial cells by necrosis or apoptosis during E. coli, S. aureus, or $S$. uberis mastitis (Bayles et al. 1998; Long et al. 2001; Singh et al. 2006) or either by downregulation of milk genes.

Most of the pathogens involved in mastitis induce cellular apoptosis during infections (Weinrauch and Zychlinsky 1999). Experimentally induced mastites with E. coli (Long et al. 2001), S. uberis (Swanson et al. 2009) and S. agalactiae (Sheffield 1997) promote apoptosis and cell proliferation. The increased apoptosis can be explained by the induction of pro-apoptotic cytokines such as TNF- $\alpha$ (Mebmer et al. 1999) or IL-1. Increased cell proliferation may be part of the self-cure after mastitis. Besides, S. aureus (Bayles et al. 1998) and S. dysgalactiae (Almeida and Oliver 1995) can be internalized by epithelial or endothelial cells and can thus induce apoptosis of bovine mammary epithelial cells.

$E$. coli and $S$. aureus have been shown to induce necrosis of the mammary epithelium, especially during severe mastitis (Zhao and Lacasse 2008). E. coli produces proteinases that contribute to the degradation of extracellular matrices (Haddadi et al. 2005; Haddadi et al. 2006). Total level of gelatinases (notably matrix metalloproteinases, MMP-2, and MMP-9), which destroy basal membrane and interstitial tissue proteins was actually 300 -fold higher in milk from cows with $E$. coli mastitis than in milk from healthy cows and they injured the basal membrane and interstitial tissues (Raulo et al. 2002). S. aureus infected quarters present less alveolar luminal area and more stromal area than uninfected quarters and thus exhibited less secretory and synthetic ability (Sordillo et al. 1989).

Downregulation of genes implied in milk component synthesis could be explained by a direct role of pathogens or by an increase in cytokines. Some 
cytokines can actually directly induce suppression of some protein secretion. For example, injection of IL- 8 induced a decrease in $\alpha$-, $\beta$-caseins suggesting that IL8 is involved in suppressing the secretion of milk-specific proteins (Watanabe et al. 2008). TNF- $\alpha$ has an impact on mammary epithelial cells (Ip et al. 1992; Rejman et al. 1993). Injection of recombinant TNF- $\alpha$ induced a decrease in milk production, in protein content of milk and an increase in fat content (Kushibiki et al. 2003). TNF- $\alpha$ was also shown to inhibit casein secretion by bovine cells in vitro (Hurley et al. 1994 ) and to induce a decrease in $\alpha$-casein, $\beta$-casein, $\alpha$-lactalbumin, and $\beta$ lactoglobulin concentrations in milk (Watanabe et al. 2000). The presence of TNF- $\alpha$ in the mammary gland induced an increase in lactoferrin concentration (Watanabe et al. 2000) although it has been shown that TNF- $\alpha$ does not directly induce lactoferin production (Hurley et al. 1994): effects of some cytokines or hormones can indeed be mediated by TNF- $\alpha$ (Cerami 1992), which could explain the increase of lactoferrin in the mammary gland after TNF- $\alpha$ injection.

$E$. coli induced a complete reprogramming of the metabolism of the mammary gland during infection (Gunther et al. 2009): within 24 h, E. coli mastitis induced a downregulation of "lactation" genes and an upregulation of "defense" genes via remethylation of some promoter areas such as the $\alpha_{\mathrm{S} 1}$-casein promoter, which results in a complete shut-down of casein synthesis (Vanselow et al. 2006). On the contrary, subclinical $S$. aureus mastitis is characterized by a sustained casein synthesis and no remethylation of the genes remethylized during coliform mastitis (Vanselow et al. 2006). In this way, transcription of genes encoding $\beta$-casein is not altered after $S$. aureus infusion and normal milk protein gene expression is maintained despite remodeling of the mammary gland tissue (Lutzow et al. 2008).

\subsection{Plasmin increase during mastitis}

Plasmin is a serine protease that plays a role in several physiological processes in mammals. For example, it is a key enzyme in fibrinolysis or degrades various extracellular matrix components. Its inactive precursor is plasminogen, whose conversion to plasmin is activated by proteolysis and regulated by activators and inhibitors (Lahteenmaki et al. 2001). Plasmin is the main proteinase in bovine milk. It hydrolyses $\beta$ - and $\alpha_{\mathrm{S} 2}$-caseins, and, more slowly, $\alpha_{\mathrm{S} 1^{-}}$and $\gamma$-caseins, proteose peptones, and possibly $\lambda$-casein. It has a $\mathrm{pH}$ optimum around 7.5 (Bastian and Brown 1996; Fox and McSweeney 1996). In mastitis, increased SCC has been correlated with an increased plasmin activity (Albenzio et al. 2005; Kalit et al. 2002; Politis et al. 1989a; Saeman et al. 1988; Somers et al. 2003) which can be explained by the conversion of plasminogen to plasmin (Verdi and Barbano 1991) and or by plasmin transport from blood (Politis et al. 1989b). Conversion of plasminogen to plasmin can be induced by activators, whose levels increase due to the increase in epithelial barrier permability (Dano et al. 1985) and to their synthesis by PMN (Moir et al. 2001; Politis et al. 1991). Other physiological components (epidermal growth factor, insulin-like growth factor I, and prostaglandin E2) and some PMN proteases (elastase and cathepsin G) increase the activity of plasminogen activators (Le Roux et al. 2003).

Regardless of the bacterial species, the plasmin activity in milk from the infected glands actually increased by 2 -fold compared with uninfected quarters (Leitner et al. 2006). Moreover, milk plasmin activity appears to remain higher than before 
infection even after elimination of the infection suggesting that the detrimental effect of mastitis on milk quality persists after elimination of the infection and low SCC being achieved (Saeman et al. 1988).

It has been shown that bacteria regulate directly or indirectly plasmin activity. Streptococci produce streptokinase that forms a complex with plasminogen and plasmin and thus activates plasminogen (Lahteenmaki et al. 2001). S. uberis synthetises a streptokinase-type plasminogen activator, PauA which can activate bovine plasminogen (Rosey et al. 1999). Some species of streptococci posess a plasmin receptor (GAPDH and enolase) which can immobilize plasmin and so activates plasminogen (Berge and Sjobring 1993; Lincoln and Leigh 1998; Pancholi and Fischetti 1998). S. aureus can enhance the production of urokinase, a plasminogen activator in bovine epithelial cells. So, S. aureus contributes directly to induce an increase in plasmin concentration (Zavizion et al. 1997). Finally, $S$. aureus also plays a role in plasminogen activation through the synthesis of plasminogen receptors, which immobilize plasmin on the cell wall and so indirectly activates plasminogen (Kuusela and Saksela 1990; Kuusela et al. 1992). E. coli posesses a filamentous surface appendage fimbriae and flagella that form a class of plasminogen receptor. The flagellar filaments of E. coli bind plasminogen and induce its activation by tissue type plasminogen activator (Lahteenmaki et al. 2001).

Plasmin influences the quality of dairy products (Bastian and Brown 1996), notably by hydrolyzing caseins. This in turn influences milk coagulation properties, cheese yield (McSweeney et al. 1994) and cheese ripening (O'Farell et al. 2002). Moreover, plasmin is heat stable with large amounts surviving pasteurization. Even after UHT treatment,

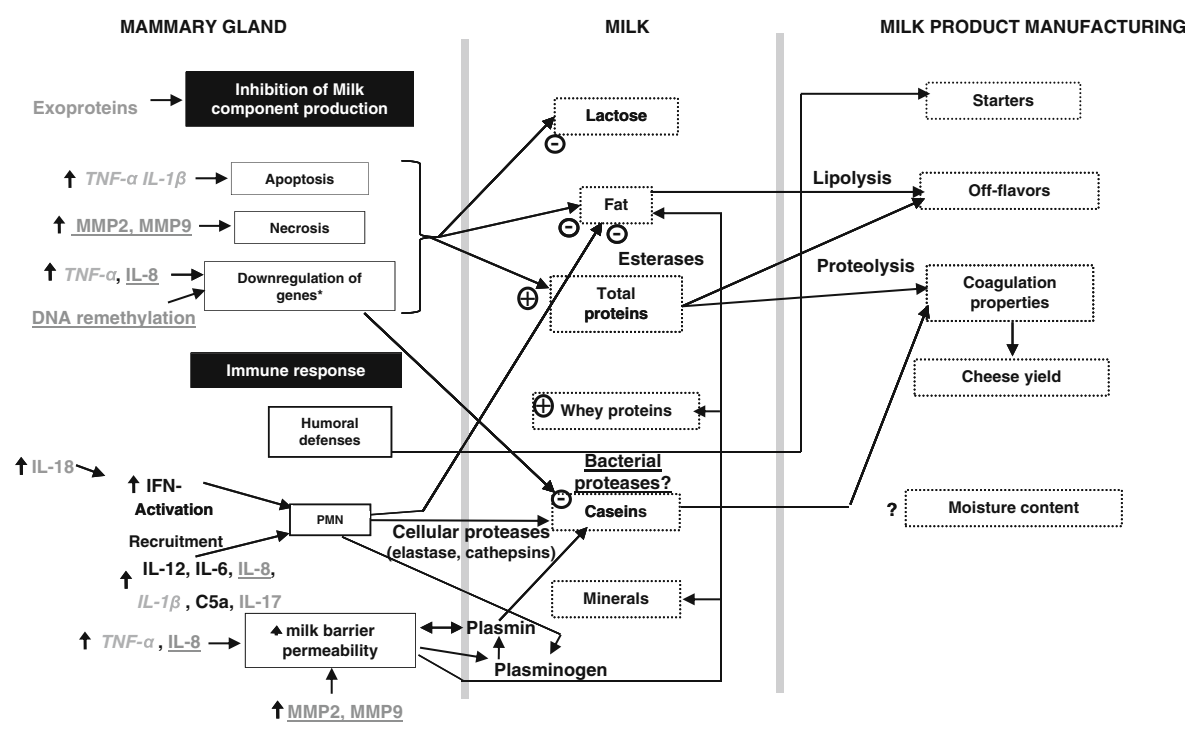

*not observed during $\mathrm{S}$. aureus subclinical mastitis

Fig. 3 Schematic view of the potential links between the impact of the three major mastitis pathogens on the mammary gland and the milk and milk products quality. Factors in grey underlined, indicate effects reported in the literature for Escherichia coli; in grey, effects reported for Staphylococcus aureus; in italic, effects reported for both Streptococcus uberis and E. coli; in black underlined, both S. aureus and E. coli; in black, S. uberis, S. aureus, and E. coli. Minus and plus symbols indicate an inhibition and an activation, respectively. Question marks indicate that the relationship is suspected but not clearly demonstrated 
$30 \%$ to $40 \%$ of plasmin activity can be detected in the milk (Alichanidis et al. 1986). Proteolysis of $\beta$-casein by plasmin has been shown to play a role in cheese flavor enhancement (Farkye and Landkammer 1992; Farkye and Fox 1992). Plasmin activity changes according to the $\mathrm{pH}$ and so varies from one dairy product to another. For example, it slightly increases during cheddar (Barrett et al. 1999) or Danbo (Benfeldt et al. 1997) cheese ripening and decreases during Saint-Paulin cheese ripening (Bastian et al. 1991). It appears that proteolysis due to plasmin produces off-flavors earlier than lipolysis due to lipase in pasteurized milk with high SCC (Ma et al. 2000).

\section{Conclusions}

Mastitic milk costs amount to billion dollar losses for dairy factories worldwide (Napoli et al. 2007). In most studies, the increase in SCC is considered a marker of mastitic milk. Numerous studies have reported on the impact of an increased SCC on milk and subsequent changes in most parameters related to the biochemical aspects and cheese processing. These modifications in the milk composition have a variable impact on the quality of dairy products. In general, an increase in SCC has a negative influence on cheese processing and in pasteurized milk grading during storage. The scientific literature is quite abundant regarding these observed impacts but nevertheless, the reported observations sometimes appear contradictory. Besides, more and more is known regarding the impact of various pathogenic bacteria on the mammary gland physiology upon intramammary infection. Some recent advances in the bacteria-host interactions have revealed that the udder response to the infection might differ from one pathogen to another. This review shows that some intriguing observations in the field of SCC and milk modifications could be explained by the specific bacteria-host interactions. It appears that a gap exists between these two scientific fields. An attempt to link these two fields is presented in Fig. 3. In the future, it would be more accurate and would result in clearer conclusions if the phenomenon was studied as a whole, including relationships between the nature of the mastitis causative agents, and the subsequent impacts on udder (including SCC as one parameter among others), milk quality and milk products, especially when subclinical mastitis is considered because such milks are collected, processed and used for human consumption. Identifying the causative pathogens rather than using the increase in SCC so as to detect mastitis may be more relevant, notably in order to determine if the milk can be used and to which extent.

Acknowledgments Caroline Le Maréchal is the recipient of a Ph.D. grant from the Institut National de la Recherche Agronomique (INRA) and the Agence Nationale de Sécurité Sanitaire (ANSES), IMISa Project.

\section{References}

Albenzio M, Caroprese M, Santillo A, Marino R, Taibi L, Sevi A (2004) Effects of somatic cell count and stage of lactation on the plasmin activity and cheese-making properties of ewe milk. J Dairy Sci $87: 533-542$ 
Albenzio M, Caroprese M, Santillo A, Marino R, Muscio A, Sevi A (2005) Proteolytic patterns and plasmin activity in ewes' milk as affected by somatic cell count and stage of lactation. J Dairy Res 72:86-92

Ali EA, Andrews AT, Cheeseman GC (1980) Influence of elevated somatic cell count on casein distribution and cheese-making. J Dairy Res 47:393-400

Alichanidis E, Polychroniadou A (1995) Special features of dairy products from ewe and goat milk from the physiochemicaland organoleptic point of view. In: IDF Greek National Committee of IDF CIRVAL Seminar, Creta, Greece, 21-10-1995, 122-127

Alichanidis E, Wrathall JHM, Andrews AT (1986) Heat-stability of plasmin (milk proteinase) and plasminogen. J Dairy Res 53:259-269

Alluwaimi AM, Leutenegger CM, Farver TB, Rossitto PV, Smith WL, Cullor JS (2003) The cytokine markers in Staphylococcus aureus mastitis of bovine mammary gland. J Vet Med B Infect Dis Vet Public Health 50:105-111

Almeida RA, Oliver SP (1995) Invasion of bovine mammary epithelial cells by Streptococcus dysgalactiae. J Dairy Sci 78:1310-1317

Anderson M (1982) Factors affecting the distribution of lipoprotein lipase activity between serum and casein micelles in bovine milk. J Dairy Res 49:51-59

Anderson M, Andrews AT (1977) Progressive changes in individual milk protein concentrations associated with high somatic cell counts. J Dairy Res 44:223-235

Andreatta E, Fernandes AM, dos Santos MV, de Lima CG, Mussarelli C, Marquesi MC, de Oliveira CAF (2007) Effects of milk somatic cell count on physical and chemical characteristics of mozzarella cheese. Aust J Dairy Technol 62:166-170

Ariznabarreta A, Gonzalo C, San Primitivo F (2002) Microbiological quality and somatic cell count of ewe milk with special reference to staphylococci. J Dairy Sci 85:1370-1375

Ashworth US, Forster TL, Luedecke LO (1967) Relationship between California mastitis test reaction and composition of milk from opposite quarters. J Dairy Sci 50:1078-1082

Auldist MJ, Hubble IB (1998) Effects of mastitis on raw milk and dairy products. Aust J Dairy Technol $53: 28-36$

Auldist MJ, Coats S, Rogers GL, McDowell GH (1995) Changes in the composition of milk from normal and mastitic dairy cows during the lactation cycle. Aust J Exp Agric 35:427-436

Auldist MJ, Coats S, Sutherland BJ, Mayes JJ, McDowell GH, Rogers GL (1996) Effects of somatic cell count and stage of lactation on raw milk composition and the yield and quality of Cheddar cheese. J Dairy Res 63:269-280

Azzara CD, Dimick PS (1985a) Lipolytic enzyme-activity of macrophages in bovine mammary-gland secretions. J Dairy Sci 68:1804-1812

Azzara CD, Dimick PS (1985b) Lipoprotein lipase activity of milk from cows with prolonged subclinical mastitis. J Dairy Sci 68:3171-3175

Bachman KC, Hayen MJ, Morse D, Wilcox CJ (1988) Effect of pregnancy, milk yield, and somatic cell count on bovine milk fat hydrolysis. J Dairy Sci 71:925-931

Ballou LU, Pasquini M, Bremel RD, Everson T, Sommer D (1995) Factors affecting herd milk composition and milk plasmin at four levels of somatic cell counts. J Dairy Sci 78:2186-2195

Bank U, Ansorge S (2001) More than destructive: neutrophil-derived serine proteases in cytokine bioactivity control. J Leukoc Biol 69:197-206

Bannerman DD (2009) Pathogen-dependent induction of cytokines and other soluble inflammatory mediators during intramammary infection of dairy cows. J Anim Sci 87:10-25

Bannerman DD, Paape MJ, Goff JP, Kimura K, Lippolis JD, Hope JC (2004a) Innate immune response to intramammary infection with Serratia marcescens and Streptococcus uberis. Vet Res 35:681-700

Bannerman DD, Paape MJ, Lee JW, Zhao X, Hope JC, Rainard P (2004b) Escherichia coli and Staphylococcus aureus elicit differential innate immune responses following intramammary infection. Clin Diagn Lab Immunol 11:463-472

Bannerman DD, Paape MJ, Chockalingam A (2006) Staphylococcus aureus intramammary infection elicits increased production of transforming growth factor- $\alpha, \beta 1$, and $\beta 2$. Vet Immunol Immunopathol 112:309-315

Bansal BK, Hamann J, Grabowskit NT, Singh KB (2005) Variation in the composition of selected milk fraction samples from healthy and mastitic quarters, and its significance for mastitis diagnosis. J Dairy Res 72:144-152

Baranova VS, Belov AD (1993) Cow milk proteins during mastitis infections. Voprosy Vet Biol 33-35

Barbano DM, Rasmussen RR, Lynch JM (1991) Influence of milk somatic-cell count and milk age on cheese yield. J Dairy Sci 74:369-388 
Barbano DM, Ma Y, Santos MV (2006) Influence of raw milk quality on fluid milk shelf life. J Dairy Sci 89:E15-E19

Bareille N, Beaudeau F, Billon S, Robert A, Faverdin P (2003) Effects of health disorders on feed intake and milk production in dairy cows. Livest Prod Sci 83:53-62

Barlowska J, Litwinczuk Z, Wolanciuk A, Brodziak A (2009) Relationship of somatic cell count to daily yield and technological usefulness of milk from different breeds of cows. Pol J Vet Sci 12:75-79

Barrett FM, Kelly AL, McSweeney PLH, Fox PF (1999) Use of exogenous urokinase to accelerateproteolysis in Cheddar cheese during ripening. Int Dairy J 9:421-427

Bartlett PC, van Wijk J, Wilson DJ, Green CD, Miller GY, Majewski GA, Heider LE (1991) Temporal patterns of lost milk production following clinical mastitis in a large Michigan Holstein herd. J Dairy Sci 74:1561-1572

Bastian ED, Brown RJ (1996) Plasmin in milk and dairy products: an update. Int Dairy J 6:435-457

Bastian ED, Hansen KG, Brown RJ (1991) Activation of plasmin with urokinase in ultrafilteredmilk for cheese manufacture. J Dairy Sci 74:3669-3676

Baudry C, de Cremoux R, Chartier C, Perrin G (1997) Impact of mammary gland inflammation on milk yield and composition in goats. Vet Res 28:277-286

Bayles KW, Wesson CA, Liou LE, Fox LK, Bohach GA, Trumble WR (1998) Intracellular Staphylococcus aureus escapes the endosome and induces apoptosis in epithelial cells. Infect Immun 66:336-342

Benfeldt C, Sørensen J, Ellegård K, Petersen TE (1997) Heat treatment of cheese milk: effect on plasmin activity and proteolysis during cheese ripening. Int Dairy J 7:723-731

Berge A, Sjobring U (1993) PAM, a novel plasminogen-binding protein from Streptococcus pyogenes. J Biol Chem 268:25417-25424

Bergonier D, Lagriffoul G, Berthelot X, Barillet F (1994) Facteurs de variation non infectieux des comptages cellules somatiques chez les ovins et caprines laitiers. In: Proc. Int. Symp. Somatic Cells and Milk of Small Ruminants, Bella, Italy, 25-9-1994, 1-20

Bergonier D, de Cremoux R, Rupp R, Lagriffoul G, Berthelot X (2003) Mastitis of dairy small ruminants. Vet Res 34:689-716

Bester BH, Lombard SH (1990) Influence of lysozyme on selected bacteria associated with Gouda cheese. J Food Prot 53:306-311

Bianchi L, Bolla A, Budelli E, Caroli A, Casoli C, Pauselli M, Duranti E (2004) Effect of udder health status and lactation phase on the characteristics of Sardinian ewe milk. J Dairy Sci 87:2401-2408

Boehmer JL, Bannerman DD, Shefcheck K, Ward JL (2008) Proteomic analysis of differentially expressed proteins in bovine milk during experimentally induced Escherichia coli mastitis. J Dairy Sci 91:4206-4218

Bogin E, Ziv G (1973) Enzymes and minerals in normal and mastitic milk. Cornell Vet 63:666-676

Bonnefoy A, Legrand C (2000) Proteolysis of subendothelial adhesive glycoproteins (fibronectin, thrombospondin, and von Willebrand factor) by plasmin, leukocyte cathepsin G, and elastase. Thromb Res 98:323-332

Brink N, Lewis U, Williams D (1956) Pancreatic elastase: purification, properties, and function. J Biol Chem 222:705-720

Bufano G, Dario C, Laudario V (1996) The characterisation of Leccese sheep: variations of chemical composition and lactodynamographic parameters in milk as related to somatic cell counts. In: Proceedings of the International Symposium of Somatic Cells and Milk of Small Ruminants 25-27 September 1996; Bella., Italy. 301-304

Caffin JP, Poutrel B, Rainard P (1983) Physiological and pathological factors influencing bovine immunoglobulin G1 concentration in milk. J Dairy Sci 66:2161-2166

Carlsson A, Bjorck L, Persson K (1989) Lactoferrin and lysozyme in milk during acute mastitis and their inhibitory effect in Delvotest P. J Dairy Sci 72:3166-3175

Caruolo EV (1974) Milk yield, composition, and somatic cells as a function of time of day in goats under a continuous lighting regimen. Br Vet J 130:380-387

Cerami A (1992) Inflammatory cytokines. Clin Immunol Immunopathol 62:S3-S10

Chaneton L, Tirante L, Maito J, Chaves J, Bussmann LE (2008) Relationship between milk lactoferrin and etiological agent in the mastitic bovine mammary gland. J Dairy Sci 91:1865-1873

Chen PW, Chen WC, Mao FCH (2004) Increase of lactoferrin concentration in mastitic goat milk. J Vet Med Sci 66:345-350

Chen SX, Wang JZ, Van Kessel JS, Ren FZ, Zeng SS (2010) Effect of somatic cell count in goat milk on yield, sensory quality, and fatty acid profile of semisoft cheese. J Dairy Sci 93:1345-1354

Chockalingam A, Paape MJ, Bannerman DD (2005) Increased milk levels of transforming growth factor- $\alpha, \beta 1$, and $\beta 2$ during Escherichia coli-induced mastitis. J Dairy Sci 88:1986-1993 
Considine T, Healy A, Kelly AL, McSweeney PLH (1999) Proteolytic specificity of elastase on bovine $\beta$ casein. Food Chem 66:463-470

Considine T, Healy A, Kelly AL, McSweeney PLH (2000) Proteolytic specificity of elastase on bovine as1-casein. Food Chem 69:19-26

Considine T, Geary S, Kelly AL, McSweeney PLH (2002a) Proteolytic specificity of cathepsin G on bovine $\alpha$ s1- and $\beta$-caseins. Food Chem 76:59-67

Considine T, McSweeney PLH, Kelly AL (2002b) The effect of lysosomal proteinases and plasmin on the rennet coagulation properties of skim milk. Milchwissenschaft 57:425-428

Considine T, Healy A, Kelly AL, McSweeney PLH (2004) Hydrolysis of bovine caseins by cathepsin B, a cysteine proteinase indigenous to milk. Int Dairy J 14:117-124

Cooney S, Tiernan D, Joyce P, Kelly AL (2000) Effect of somatic cell count and polymorphonuclear leucocyte content of milk on composition and proteolysis during ripening of Swiss-type cheese. J Dairy Res 67:301-307

Cooray R (1996) Casein effects on the myeloperoxidase-mediated oxygen-dependent bactericidal activity of bovine neutrophils. Vet Immunol Immunopathol 51:55-65

Coulon JB, Gasqui P, Barnouin J, Ollier A, Pradel P, Pomies D (2002) Effect of mastitis and related-germ on milk yield and composition during naturally-occurring udder infections in dairy cows. Anim Res 51:383-393

Dano K, Andreasen PA, Grondahl-Hansen J, Kristensen P, Nielsen LS, Skriver L (1985) Plasminogen activators, tissue degradation, and cancer. Adv Cancer Res 44:139-266

de Haas Y, Barkema HW, Veerkamp RF (2002) The effect of pathogen-specific clinical mastitis on the lactation curve for somatic cell count. J Dairy Sci 85:1314-1323

Devriese LA, Schleifer KH, Adegoke GO (1985) Identification of coagulase-negative staphylococci from farm animals. J Appl Bacteriol 58:45-55

Diaz JR, Muelas R, Segura R, Peris CMP (1996) Effect of mastitis on milk composition in manchega ewes: preliminary results, in: Proceedings of the International Symposium of Somatic Cells and Milk of Small Ruminants 25-27 September 1996; Bella, Italy 305-309

Djabri B, Bareille N, Beaudeau F, Seegers H (2002) Quarter milk somatic cell count in infected dairy cows: a meta-analysis. Vet Res 33:335-357

Donelly WJ, Barry JG (1983) Casein compositional studies. III. Changes in Irish milk for manufacturing and role of milk protease. J Dairy Res 50:433

Dufour D, Jameh N, Dary A, Le Roux Y (2009) Short communication: can the mammopathogenic Escherichia coli P4 strain have a direct role on the caseinolysis of milk observed during bovine mastitis? J Dairy Sci 92:1398-1403

Duranti E, Casoli C (1991) Variations in the nitrogen composition and in the lactodinamographic parameters of ewe's milk in relation to somatic cell content. Zootec Nutr Anim 17:99-105

El-Saied UM, Carriedo JA, De la Fuente LF, San Primitivo F (1999) Genetic parameters of lactation cell counts and milk and protein yields in dairy ewes. J Dairy Sci 82:639-644

Emmons DB, Elliot JA, Beckett DC (1963) Agglutination of starter bacteria, sludge formation and slow acid development in cottage cheese manufacture. J Dairy Sci 46:600

Emmons DB, Elliott JA, Beckett DC (1966) Effect of lactic-streptococcal agglutinins in milk on curd formation and manufacture of cottage cheese. J Dairy Sci 49:1361

Erwin RE, Randolph HE (1975) Influence of mastitis on properties of milk. XI. Fat globule membrane. J Dairy Sci 58:9-12

Farkye NY, Fox PF (1992) Contribution of plasmin to Cheddar cheese ripening: effect of added plasmin. J Dairy Res 59:209-216

Farkye NT, Landkammer CF (1992) Milk plasmin activity influence on cheddar cheese quality during ripening. J Food Sci 57:622-624

Fernandes AM, Oliveira CAF, Lima CG (2006) Effects of somatic cell counts in milk on physical and chemical characteristics of yoghurt. Int Dairy J 17:111-115

Fernandes AM, Moretti TS, Bovo F, Lima CG, Oliveira CAF (2008) Effect of somatic cell counts on lipolysis, proteolysis and apparent viscosity of UHT milk during storage. Int J Dairy Technol 61:327332

Fitz-Gerald CH, Deeth HC, Kitchen BJ (1981) The relationship between the levels of free fatty acids, lipoprotein lipase, carboxylesterase, $N$-acetyl-beta-D-glucosaminidase, somatic cell count and other mastitis indices in bovine milk. J Dairy Res 48:253-265

Fox PF, McSweeney PLH (1996) Proteolysis in cheese. Food Rev Int 12:457-509

Galina MA, Morales R, Lopez B, Carmona MA (1996) Effect of somatic cell count on lactation and soft cheese yield by dairy goats. Small Rumin Res 21:251-257 
Gargouri A, Hamed H, El Feki A (2008) Total and differential bulk cow milk somatic cell counts and their relation with lipolysis. Livest Sci 113:274-279

Gonzalo C, Carriedo JA, Gomez JD, Gomez LD, San PF (1994) Diurnal variation in the somatic cell count of ewe milk. J Dairy Sci 77:1856-1859

Gonzalo C, Ariznabarreta A, Carriedo JA, San Primitivo F (2002) Mammary pathogens and their relationship to somatic cell count and milk yield losses in dairy ewes. J Dairy Sci 85:14601467

Grandison AS, Ford GD (1986) Effects of variations in somatic cell count on the rennet coagulation properties of milk and on the yields, composition and quality of cheddar cheese. J Dairy Res 53:645655

Grazia LC, Castagnetti GB, Losi B (1984) Manufacture of Grana cheese with lysozyme. Acidification of whey and sensitivity of thermophilic lactic acid bacteria. Sci Tecn Latt Cas 35:384-393

Griesbeck-Zilch B, Meyer HHD, Kuhn C, Schwerin M, Wellnitz O (2008) Staphylococcus aureus and Escherichia coli cause deviating expression profiles of cytokines and lactoferrin messenger ribonucleic acid in mammary epithelial cells. J Dairy Sci 91:2215-2224

Grieve PA, Kitchen BJ (1985) Proteolysis in milk: the significance of proteinases originating from milk leucocytes and a comparison of the action of leucocyte, bacterial and natural milk proteinases on casein. J Dairy Res 52:101-112

Grohn YT, Wilson DJ, Gonzalez RN, Hertl JA, Schulte H, Bennett G, Schukken YH (2004) Effect of pathogen-specific clinical mastitis on milk yield in dairy cows. J Dairy Sci 87:3358-3374

Gunther J, Koczan D, Yang W, Nurnberg G, Repsilber D, Schuberth HJ, Park Z, Maqbool N, Molenaar A, Seyfert HM (2009) Assessment of the immune capacity of mammary epithelial cells: comparison with mammary tissue after challenge with Escherichia coli. Vet Res 40:31-45

Haddadi K, Moussaoui F, Hebia I, Laurent F, Le Roux Y (2005) E.coli proteolytic activity in milk and casein breakdown. Reprod Nutr Dev 45:485-496

Haddadi K, Prin-Mathieu C, Moussaoui F, Faure GC, Vangroenweghe F, Burvenich C, Le Roux Y (2006) Polymorphonuclear neutrophils and Escherichia coli proteases involved in proteolysis of casein during experimental E. coli mastitis. Int Dairy J 16:639-647

Haenlein GF, Schultz LH, Zikakis JP (1973) Composition of proteins in milk with varying leucocyte contents. J Dairy Sci 56:1017-1024

Hagiwara K, Yamanaka H, Hisaeda K, Taharaguchi S, Kirisawa R, Iwai H (2001) Concentrations of IL-6 in serum and whey from healthy and mastitic cows. Vet Res Commun 25:99-108

Hagiwara S, Kawai K, Anri A, Nagahata H (2003) Lactoferrin concentrations in milk from normal and subclinical mastitic cows. J Vet Med Sci 65:319-323

Hagnestam C, Emanuelson U, Berglund B (2007) Yield losses associated with clinical mastitis occurring in different weeks of lactation. J Dairy Sci 90:2260-2270

Halasa T, Nielen M, Huirne RBM, Hogeveen H (2009) Stochastic bio-economic model of bovine intramammary infection. Livest Sci 124:295-305

Harmon RJ, Schanbacher FL, Ferguson LC, Smith KL (1976) Changes in lactoferrin, immunoglobulin G, bovine serum albumin, and alpha-lactalbumin during acute experimental and natural coliform mastitis in cows. Infect Immun 13:533-542

Hettinga KA, van Valenberg HJF, Lam TJGM, van Hooijdonk ACM (2009) The origin of the volatile metabolites found in mastitis milk. Vet Microbiol 137:384-387

Hirano R, Hirano M, Oooka M, Dosako S, Nakajima I, Igoshi K (1998) Lactoperoxidase effects on rheological properties of yogurt. J Food Sci 63:35-38

Hiss S, Meyer T, Sauerwein H (2008) Lactoferrin concentrations in goat milk throughout lactation. Small Rumin Res 80:87-90

Hodgkinson A, Ross K, Fahey S, Prosser C (2008) Quantification of lactoferrin in milk from New Zealand dairy goats. In: Proceedings of the New Zealand Society of Animal Production 68th Conference, Brisbane, Australia, 24-6-2008, 166-169

Hogarth CJ, Fitzpatrick JL, Nolan AM, Young FJ, Pitt A, Eckersall PD (2004) Differential protein composition of bovine whey: a comparison of whey from healthy animals and from those with clinical mastitis. Proteomics 4:2094-2100

Hortet P, Seegers H (1998) Calculated milk production losses associated with elevated somatic cell counts in dairy cows: review and critical discussion. Vet Res 29:497-510

Hurley WL, Aslam M, Hegarty HM, Morkoc A (1994) Synthesis of lactoferrin and casein by explants of bovine mammary tissue. Cell Biol Int 18:629-637

Hurley MJ, Larsen LB, Kelly AL, McSweeney PLH (2000) The milk acid proteinase cathepsin D: a review. Int Dairy J 10:673-681 
Ip MM, Shoemaker SF, Darcy KM (1992) Regulation of rat mammary epithelial cell proliferation and differentiation by tumor necrosis factor-alpha. Endocrinology 130:2833-2844

Jaeggi JJ, Govindasamy-Lucey S, Berger YM, Johnson ME, McKusick BC, Thomas DL, Wendorff WL (2003) Hard ewe's milk cheese manufactured from milk of three different groups of somatic cell counts. J Dairy Sci 86:3082-3089

Janota BL, Glabowna M (1982) Atomic absorption spectrophotometry of milk for prognosis of mastitis. Milchwissenschaft 37:13-16

Jaubert G, Gay jacquin, Perrin G (1996) Somatic cell counts and biochemical and technological characteristics of goat milk. In: The International Symposium on Somatic Cells and Milk of Small Ruminants, Bella, italy, 25-9-1996, 263-268

Kalit S, Havranek JL, Kaps M (2002) Plasminogen activation and somatic cell count (SCC) in cheese milk: influence on Podravec cheese ripening. Milchwissenschaft 57:380-382

Kaminogawa S, Yamauchi K, Miyazawa S, Koga Y (1980) Degradation of casein components by acid protease of bovine-milk. J Dairy Sci 63:701-704

Karlsson A, Arvidson S (2002) Variation in extracellular protease production among clinical isolates of Staphylococcus aureus due to different levels of expression of the protease repressor sarA. Infect Immun 70:4239-4246

Kawai K, Hagiwara S, Anri A, Nagahata H (1999) Lactoferrin concentration in milk of bovine clinical mastitis. Vet Res Commun 23:391-398

Kelly AL, O'Flaherty F, Fox PF (2006) Indigenous proteolytic enzymes in milk: a brief overview of the present state of knowledge. Int Dairy J 16:563-572

Kitchen BJ (1981) Review of the progress of Dairy Science: bovine mastitis:milk compositional cahnges and related diagnostic tests. J Dairy Res 48:167-188

Kitchen BJ, Middleton G, Durward IG, Andrews RJ, Salmon MC (1980) Mastitis diagnostic tests to estimate mammary gland epithelial cell damage. J Dairy Sci 63:978-983

Kitchen BJ, Middleton G, Kwee WS, Andrews RJ (1984) N-Acetyl-beta-D-glucosaminidase (NAGase) levels in bulk herd milk. J Dairy Res 51:227-232

Klei L, Yun J, Sapru A, Lynch J, Barbano D, Sears P, Galton D (1998) Effects of milk somatic cell count on cottage cheese yield and quality. J Dairy Sci 81:1205-1213

Komine K, Kuroishi T, Komine Y, Watanabe K, Kobayashi J, Yamaguchi T, Kamata S, Kumagai K (2004) Induction of nitric oxide production mediated by tumor necrosis factor alpha on staphylococcal enterotoxin C-stimulated bovine mammary gland cells. Clin Diagn Lab Immunol 11:203-210

Kushibiki S, Hodate K, Shingu H, Obara Y, Touno E, Shinoda M, Yokomizo Y (2003) Metabolic and lactational responses during recombinant bovine tumor necrosis factor- $\alpha$ treatment in lactating cows. J Dairy Sci 86:819-827

Kuusela P, Saksela O (1990) Binding and activation of plasminogen at the surface of Staphylococcus aureus - increase in affinity after conversion to the lys form of the ligand. Eur J Biochem 193:759765

Kuusela P, Ullberg M, Kronvall G, Tervo T, Tarkkanen A, Saksela O (1992) Surface-associated activation of plasminogen on gram-positive bacteria - effect of plasmin on the adherence of Staphylococcus aureus. Acta Ophthalmol 70:42-46

Lahteenmaki K, Kuusela P, Korhonen TK (2001) Bacterial plasminogen activators and receptors. FEMS Microbiol Rev 25:531-552

Larsen LB, Benfeldt C, Rasmussen LK, Petersen TE (1996) Bovine milk procathepsin D and cathepsin D: coagulation and milk protein degradation. J Dairy Res 63:119-130

Larsen LB, Wium H, Benfeldt C, Heegaard CW, Ardo Y, Qvist KB, Petersen TE (2000) Bovine milk procathepsin D: presence and activity in heated milk and in extracts of rennet-free UF-Feta cheese. Int Dairy J 10:67-73

Larsen LB, Rasmussen MD, Bjerring M, Nielsen JH (2004) Proteases and protein degradation in milk from cows infected with Streptococcus uberis. Int Dairy J 14:899-907

Larsen LB, McSweeney PLH, Hayes MG, Andersen JB, Ingvartsen KL, Kelly AL (2006) Variation in activity and heterogeneity of bovine milk proteases with stage of lactation and somatic cell count. Int Dairy J 16:1-8

Laurinaviciute V, Siugzdaite J, Urbsienne D (2004) Quality and composition of milk with different somatic cell count of two breeds of dairy goats. Med Weter 60:1137-1248

Le Mens P, Dalmas S, Humbert G (1996) Relations entre l'activité de la N-acetyl-glucosaminidase (NAG-ase), le nombre de cellules,l'aptitude à la coagulation du lait et le statut infectieux mammairechez la chèvre, In: Proceedings of the International Symposium on Somatic Cells and Milk of Small Ruminants, Bella,Italy, 25-9-1996, 311-312 
Le Roux Y, Colin O, Laurent F (1995) Proteolysis in samples of quarter milk with varying somatic cell counts. 1. Comparison of some indicators of endogenous proteolysis in milk. J Dairy Sci 78:12891297

Le Roux Y, Laurent F, Moussaoui F (2003) Polymorphonuclear proteolytic activity and milk composition change. Vet Res 34:629-645

Leavitt BE, Oleary J, Harmon RJ, Hicks CL (1982) Effect of mastitis on cheese yield, milk-production, milk-composition and starter culture activity. J Food Prot 45:1176

Lee SC, Yu JH, Back YJ, Yoon YC (1991) The influence of mastitis on the quality of raw milk and cheese. Kor J Dairy Sci 13:217-223

Lee JW, Paape MJ, Zhao X (2003) Recombinant bovine soluble CD14 reduces severity of experimental Escherichia coli mastitis in mice. Vet Res 34:307-316

Lee JW, Bannerman DD, Paape MJ, Huang MK, Zhao X (2006) Characterization of cytokine expression in milk somatic cells during intramammary infections with Escherichia coli or Staphylococcus aureus by real-time PCR. Vet Res 37:219-229

Lehtolainen T, Rontved C, Pyorala S (2004) Serum amyloid A and TNF alpha in serum and milk during experimental endotoxin mastitis. Vet Res 35:651-659

Leitner G, Chaffer M, Caraso Y, Ezra E, Kababea D, Winkler M, Glickman A, Saran A (2003) Udder infection and milk somatic cell count, NAGase activity and milk composition-fat, protein and lactose-in Israeli-Assaf and Awassi sheep. Small Rumin Res 49:157-164

Leitner G, Chaffer M, Shamay A, Shapiro F, Merin U, Ezra E, Saran A, Silanikove N (2004a) Changes in milk composition as affected by subclinical mastitis in sheep. J Dairy Sci 87:46-52

Leitner G, Merin U, Silanikove N (2004b) Changes in milk composition as affected by subclinical mastitis in goats. J Dairy Sci 87:1719-1726

Leitner G, Merin U, Silanikove N, Ezra E, Chaffer M, Gollop N, Winkler M, Glickman A, Saran A (2004c) Effect of subclinical intramammary infection on somatic cell counts, NAGase activity and gross composition of goats' milk. J Dairy Res 71:311-315

Leitner G, Krifucks O, Merin U, Lavi Y, Silanikove N (2006) Interactions between bacteria type, proteolysis of casein and physico-chemical properties of bovine milk. Int Dairy J 16:648-654

Lemieux L, Simard RE (1994) Astringency, a textural defect in dairy-products. Lait 74:217-240

Lincoln RA, Leigh JA (1998) Characterization of the interaction of bovine plasmin with Streptococcus uberis. J Appl Microbiol 84:1104-1110

Long E, Capuco AV, Wood DL, Sonstegard T, Tomita G, Paape MJ, Zhao X (2001) Escherichia coli induces apoptosis and proliferation of mammary cells. Cell Death Differ 8:808-816

Lucas PS (1962) What causes a spongy formation in cottage cheese? Am Milk Rev 24:74

Lucey S, Rowlands GJ, Russell AM (1986) Short-term associations between disease and milk yield of dairy cows. J Dairy Res 53:7-15

Lutzow YC, Donaldson L, Gray CP, Vuocolo T, Pearson RD, Reverter A, Byrne KA, Sheehy PA, Windon R, Tellam RL (2008) Identification of immune genes and proteins involved in the response of bovine mammary tissue to Staphylococcus aureus infection. BMC Vet Res 4:18

Ma Y, Ryan C, Barbano DM, Galton DM, Rudan MA, Boor KJ (2000) Effects of somatic cell count on quality and shelf-life of pasteurized fluid milk. J Dairy Sci 83:264-274

Manser PA (1986) Prevalence, causes and laboratory diagnosis of subclinical mastitis in the goat. Vet Rec 118:552-554

Marino R, Considine T, Sevi A, McSweeney PLH, Kelly AL (2005) Contribution of proteolytic activity associated with somatic cells in milk to cheese ripening. Int Dairy J 15:1026-1033

Mazal G, Vianna PCB, Santos MV, Gigante ML (2007) Effect of somatic cell count on Prato cheese composition. J Dairy Sci 90:630-636

McSweeney PLH, Walsh EM, Fox PF, Cogan TM, Drinan FD, Castelo-Gonzalez M (1994) A procedure for the manufacture of cheddar cheese under controlled bacteriological conditions and the effect of adjunct lactobacilli on cheese quality. Ir J Agric Food Res 33:183-192

McSweeney PLH, Fox PF, Olson NF (1995) Proteolysis of bovine caseins by cathepsin-D - preliminaryobservations and comparison with chymosin. Int Dairy J 5:321-336

Mebmer UK, Briner VA, Pfeilschifter J (1999) Tumor necrosis factor-a and lipopolysaccharide induce apoptotic cell death in bovine glomerular endothelial cells. Kidney Int 55:2322-2337

Merin U, Fleminger G, Komanovsky J, Silanikove N, Bernstein S, Leitner G (2008) Subclinical udder infection with Streptococcus dysgalactiae impairs milk coagulation properties: the emerging role of proteose peptones. Dairy Sci Technol 88:407-419

Michelutti I, Le Roux Y, Rainard P, Poutrel B, Laurent F (1999) Sequential changes in milk protein composition after experimental Escherichia coli mastitis. Lait 79:535-549 
Miedzobrodzki J, Naidu AS, Watts JL, Ciborowski P, Palm K, Wadstrom T (1989) Effect of milk on fibronectin and collagen type I binding to Staphylococcus aureus and coagulase-negative staphylococci isolated from bovine mastitis. J Clin Microbiol 27:540-544

Miller RH, Emanuelsson U, Persson E, Brolund E, Philipsson L, Funke H (1983) Relationships of milk somatic cell counts to daily milk yield and composition. Acta Agric Scand 33:209-223

Mitchell GE, Rogers SA, Houlihan DB, Tucker VC, Kitchen BJ (1986) The relationshiop between somatic cell count, composition and manufacturing properties of bulk milk. 1. Composition of farm bulk milk. Aust J Dairy Technol 41:9-12

Moir E, Booth NA, Bennett B, Robbie BA (2001) Polymorphonuclear leukocytes mediate endogenous thrombus lysis via a uPA-dependent mechanism. Brit J Haematol 113:72-80

Morgan F, Gaspard CE (1999) Influence des cellules somatiques sur les qualités technologiques du lait de chèvre et sur les caractéristiques des fromages de chèvre, in: 6èmes journées Rencontres Recherches Ruminants, Paris, France, p 317

Moussaoui F, Michelutti I, Le Roux Y, Laurent F (2002) Mechanisms involved in milk endogenous proteolysis induced by a lipopolysaccharide experimental mastitis. J Dairy Sci 85:2562-2570

Moussaoui F, Laurent F, Girardet JM, Humbert G, Gaillard JL, Le Roux Y (2003) Characterization and proteolytic origins of specific peptides appearing during lipopolysaccharide experimental mastitis. J Dairy Sci 86:1163-1170

Moussaoui F, Vangroenweghe F, Haddadi K, Le Roux Y, Laurent F, Duchateau L, Burvenich C (2004) Proteolysis in milk during experimental Escherichia coli mastitis. J Dairy Sci 87:2923-2931

Muir DD (1996) The shelf-life of dairy products.1. Factors influencing raw milk and fresh products. J Soc Dairy Technol 49:24-32

Munro GL, Grieve PA, Kitchen BJ (1984) Effects of mastitis on milk yield, milk composition, processing properties and yield and quality of milk products. Aust J Dairy Technol 39:7-16

Murphy SC, Cranker K, Senyk GF, Barbano DM, Saeman AI, Galton DM (1989) Influence of bovine mastitis on lipolysis ond proteolysis in milk. J Dairy Sci 72:620-626

Nabhan MA, Girardet JM, Campagna S, Gaillard JL, Le Roux Y (2004) Isolation and characterization of copolymers of $\beta$-lactoglobulin, $\alpha$-lactalbumin, $\mathrm{K}$-casein, and $\alpha\left(\mathrm{S}_{1}\right)$-casein generated by pressurization and thermal treatment of raw milk. J Dairy Sci 87:3614-3622

Nakajima Y, Mikami O, Yoshioka M, Motoi Y, Ito T, Ishikawa Y, Fuse M, Nakano K, Yasukawa K (1997) Elevated levels of tumor necrosis factor-alpha (TNF-alpha) and interleukin-6 (IL-6) activities in the sera and milk of cows with naturally occurring coliform mastitis. Res Vet Sci 62:297-298

Napoli A, Aiello D, Di Donna L, Prendushi H, Sindona G (2007) Exploitation of endogenous protease activity in raw mastitic milk by MALDI-TOF/TOF. Anal Chem 79:5941-5948

Neviani EM, Tarelli GT, Divizia R (1996) Lysozyme resistance of lactic acid bacteria. Latte 3:90-91

Nudda A, Feligini M, Battacone G, Macciota NPP, Pulina G (2003) Effects of lactation stage, parity, $\beta$ lactoglobulin genotype and milk SCC on whey protein composition in Sarda dairy ewes. Ital J Anim Sci 2:29-39

O'Brien B, Meaney WJ, McDonagh D, Kelly A (2001) Influence of somatic cell count and storage interval on composition and processing characteristics of milk from cows in late lactation. Aust J Dairy Technol 56:213-218

O’Driscoll BM, Rattray FP, McSweeney PLH, Kelly AL (1999) Protease activities in raw milk determined using a synthetic heptapeptide substrate. J Food Sci 64:606-611

O'Farell P, Sheenan JJ, Wilkinson MG, Harrington D, Kelly AL (2002) Influence of addition of plasmin or mastitic milk to cheese milk on quality of smear-ripened cheese. Lait 82:305-316

Ogola H, Shitandi A, Nanua J (2007) Effect of mastitis on raw milk compositional quality. J Vet Sci 8:237-242

Ohtsuka H, Kudo K, Mori K, Nagai F, Hatsugaya A, Tajima M, Tamura K, Hoshi F, Koiwa M, Kawamura S (2001) Acute phase response in naturally occurring coliform mastitis. J Vet Med Sci 63:675-678

Oliveira CAF, Fernandes AM, Neto OCC, Fonseca LFL, Silva EOT, Balian SC (2002) Composition and sensory evaluation of whole yogurt produced from milk with different somatic cell counts. Aust J Dairy Technol 57:192-196

Ollivier-Bousquet M (1998) Transferrin and prolactin transcytosis in the lactating mammary epithelial cell. J Mammary Gland Biol Neoplasia 3:303-313

Opdenakker G, van den Steen PE, van Damme J (2001) Gelatinase B: a tuner and amplifier of immune functions. Trends Immunol 22:571-579

Ostdal H, Bjerrum MJ, Pedersen JA, Andersen HJ (2000) Lactoperoxidase-induced protein oxidation in milk. J Agric Food Chem 48:3939-3944 
Ostergaard S, Grohn YT (1999) Effects of diseases on test day milk yield and body weight of dairy cows from Danish research herds. J Dairy Sci 82:1188-1201

Othmane MH, Carriedo JA, De la Fuente LF, San Primitivio F (2002) Factors affecting test-day milk composition in dairy ewes, and relationships amongst various milk components. J Dairy Res 69:53-62

Ottogalli GA, Galli LL, Camaschella P (1983) Effect of lysozyme hydrochloride (Afilact) on lactic acid bacteria in whey starters for Grana cheese. Ind Latte 1983:43-48

Ozer B, Grandison A, Robinson R, Atamer M (2003) Effects of lactoperoxidase and hydrogen peroxide on rheological properties of yoghurt. J Dairy Res 70:227-232

Pancholi V, Fischetti VA (1998) $\alpha$-enolase, a novel strong plasmin(ogen) binding protein on the surface of pathogenic streptococci. J Biol Chem 273:14503-14515

Pasquini LU, Greppi GF, Ballou RD, Bremel RD (1996) Detection of proteolytic degradation of milk proteins and relationship with different levels of SCC in Italian goats. In: The International Symposium on Somatic Cells and Milk of Small Ruminants, Bella, Italy, 25-9-1996, pp 275-281

Pasquini S, Peralta S, Missiaglia E, Carta L, Lemoine NR (2002) Prime-boost vaccines encoding an intracellular idiotype/GM-CSF fusion protein induce protective cell-mediated immunity in murine pre-B cell leukemia. Gene Ther 9:503-510

Pellegrini O, Remeuf F, Rivemale M, Barillet F (1997) Renneting properties of milk from individual ewes: influence of genetic and non-genetic variables, and relationship with physicochemical characteristics. J Dairy Res 64:355-366

Pirisi A, Piredda G, Podda F, Pintus S (1996) Effect of somatic cell count on sheep milk composition and cheese-making properties. Somat Cells Milk Small Rumin 245-251

Pirisi A, Piredda G, Corona M, Pes M, Pintus S, Ledda A (2000) Influence of somatic cell count on ewe's milk composition, cheese yield and cheese quality. In: Proceedings of 6th Great lakes Dairy Sheep Symposium, Guelph, Canada, pp 47-59

Pisoni G, Fusi E, Cheli F, Rebucci R, Moroni P, Balci A (2004a) Changes in milk composition in dairy goast as affected by subclinical infection with Staphylococcus aureus. In: Book of abstracts of The 8th International Conference on Goats, South Africa, 4-7-2004, p 63

Pisoni G, Fusi E, Cheli F, Rebucci R, Moroni P, Baldi A (2004b) Mammary gland health status and plasmin-plasminogen systemin dairy goat. In: Book of Abstracts of the 8th InternationalConference on Goats, South Africa, 4-7-2004, p 90

Pizzillo M, Cogliandro E, Rubino R, Fedele V (1996) Relationship between somatic cells and milk quality in different goat production systems. In: Proceedings of the International Symposium on Somatic Cells and Milk of Small Ruminants, Bella, Italy, 25-9-1996, pp 269-273

Politis I, Ng-Kwai-Hang KF (1988a) Association between somatic cell count of milk and cheese yielding capacity. J Dairy Sci 71:1720-1727

Politis I, Ng-Kwai-Hang KF (1988b) Effects of somatic cell count on milk composition and cheese making efficiency. J Dairy Sci 71:1711-1719

Politis I, Hang KFNK, Giroux RN (1989a) Environmental-factors affecting plasmin activity in milk. J Dairy Sci 72:1713-1718

Politis I, Lachance E, Block E, Turner JD (1989b) Plasmin and plasminogen in bovine milk: a relationship with involution? J Dairy Sci 72:900-906

Politis I, Zhao X, McBride BW, Burton JH, Turner JD (1991) Plasminogen activator production by bovine milk macrophages and blood monocytes. Am J Vet Res 52:1208-1213

Poutrel B, Caffin JP, Rainard P (1983) Physiological and pathological factors influencing bovine serum albumin content of milk. J Dairy Sci 66:535-541

Prin-Mathieu C, Le Roux Y, Faure GC, Laurent F, Bene MC, Moussaoui F (2002) Enzymatic activities of bovine peripheral blood leukocytes and milk polymorphonuclear neutrophils during intramammary inflammation caused by lipopolysaccharide. Clin Diagn Lab Immunol 9:812-817

Pyörälä S (2003) Indicators of inflammation in the diagnosis of mastitis. Vet Res 34:565-578

Rainard P, Caffin JP (1983) Sequential-changes in serum-albumin, immunoglobulin (Igg1, Igg2, Igm) and lactoferrin concentrations in milk following infusion of Escherichia coli into the udder of immunized and unimmunized cows. Ann Rech Vét 14:271-279

Rainard P, Riollet C (2006) Innate immunity of the bovine mammary gland. Vet Res 37:369-400

Rainard P, Poutrel B, Caffin JP (1982) Lactoferrin and transferrin in bovine milk in relation to certain physiological and pathological factors. Ann Rech Vét 13:321-328

Rajala-Schultz PJ, Grohn YT, McCulloch CE, Guard CL (1999) Effects of clinical mastitis on milk yield in dairy cows. J Dairy Sci 82:1213-1220

Rambeaud M, Almeida RA, Pighetti GM, Oliver SP (2003) Dynamics of leukocytes and cytokines during experimentally induced Streptococcus uberis mastitis. Vet Immunol Immunopathol 96:193-205 
Randolph HE, Erwin RE (1974) Influence of mastitis on properties of milk. X. Fatty acid composition. J Dairy Sci 57:865-868

Raulo SM, Sorsa T, Tervahartiala T, Latvanen T, Pirila E, Hirvonen J, Maisi P (2002) Increase in milk metalloproteinase activity and vascular permeability in bovine endotoxin-induced and naturally occurring Escherichia coli mastitis. Vet Immunol Immunopathol 85:137-145

Raynal-Ljutovac K, Gaborit P, Lauret A (2005) The relationship between quality criteria of goat milk, its technological properties and the quality of the final products. Small Rumin Res 60:167-177

Raynal-Ljutovac K, Pirisi A, De Cremoux R, Gonzalo C (2007) Somatic cells of goat and sheep milk: analytical, sanitary, productive and technological aspects. Small Rumin Res 68:126-144

Reed SB, Wesson CA, Liou LE, Trumble WR, Schlievert PM, Bohach GA, Bayles KW (2001) Molecular characterization of a novel Staphylococcus aureus serine protease operon. Infect Immun 69:15211527

Rejman JJ, Turner JD, Oliver SP (1993) Influence of recombinant bovine cytokines on proliferation of a bovine mammary epithelial cell line. Cell Biol Int 17:619-621

Revilla I, Rodriguez-Nogales JM, Vivar-Quintana AM (2007) Proteolysis and texture of hard ewes' milk cheese during ripening as affected by somatic cell counts. J Dairy Res 74:127-136

Revilla I, Rodriguez-Nogales JM, Vivar-Quintana AM (2009) Effect of somatic cell counts on ewes' milk protein profile and cheese-making properties in different sheep breeds reared in Spain. J Dairy Res 76:210-215

Riollet C, Rainard P, Poutrel B (2000) Differential induction of complement fragment C5a and inflammatory cytokines during intramammary infections with Escherichia coli and Staphylococcus aureus. Clin Diagn Lab Immunol 7:161-167

Rogers SA, Mitchell GE (1994) The relationship between somatic-cell count, composition and manufacturing properties of bulk milk: cheddar cheese and skim-milk yogurt. Aust J Dairy Technol 49:70-74

Rogers SA, Mitchell GE, Bartley JP (1989a) The relationship between somatic cell count, composition and manufacturing properties of bulk milk. 4. Non-protein constituents. Aust J Dairy Technol 44:5356

Rogers SA, Slattery SL, Mitchell GE, Hirst PA, Grieve PA (1989b) The relationship between somatic cell count, composition and manufacturing properties of bulk milk. 3.Individual proteins. Aust J Dairy Technol 44:49-52

Romero G, Sendra E, Muelas R, az-Sanchez JR (2010) Effect of electrical conductivity of goat's milk on characteristics of fresh cheese. Milchwissenschaft 65:56-59

Rosey EL, Lincoln RA, Ward PN, Yancey RJ, Leigh JA (1999) PauA: a novel plasminogen activator from Streptococcus uberis (vol 178, pg 27, 1999). FEMS Microbiol Lett 180:353

Rouseff RL (1990) Bitterness in food products: an overview. In: Rousseff RL (ed) Bitterness in foods and beverages. Elsevier, Amsterdam, pp 1-14

Saeman AI, Verdi RJ, Galton DM, Barbano DM (1988) Effect of mastitis on proteolytic activity in bovine-milk. J Dairy Sci 71:505-512

Salih AM, Anderson M (1979) Observations on the influence of high cell count on lipolysis in bovine milk. J Dairy Res 46:453-462

Salih MA, Sandine WE (1980) Lactic streptococcal agglutinins: a review. J Food Prot 43:856

Salih MA, Sandine WE (1984) Rapid test for detecting lactic streptococcal agglutinins in cheese milk. J Dairy Sci 67:7-23

Sanchez L, Lujan L, Oria R, Castillo H, Perez D, Ena JM, Calvo M (1992) Synthesis of lactoferrin and transport of transferrin in the lactating mammary-gland of sheep. J Dairy Sci 75:1257-1262

Santos MV, Ma Y, Barbano DM (2003) Effect of somatic cell count on proteolysis and lipolysis in pasteurized fluid milk during shelf-life storage. J Dairy Sci 86:2491-2503

Santos JE, Cerri RL, Ballou MA, Higginbotham GE, Kirk JH (2004) Effect of timing of first clinical mastitis occurrence on lactational and reproductive performance of Holstein dairy cows. Anim Reprod Sci $80: 31-45$

Schalm OW, Carroll EJ, Jain NC (1971) Bovine mastitis. Lea \&Febiger, Philadelphia

Schanbacher FL, Smith KL (1975) Formation and role of unusual whey proteins and enzymes: relation to mammary function. J Dairy Sci 58:1048-1062

Scharfen EC, Mills DA, Maga EA (2007) Use of human lysozyme transgenic goat milk in cheese making: effects on lactic acid bacteria performance. J Dairy Sci 90:4084-4091

Schmedt Auf Der Gunne H, Tenhagen BA, Kutzer P, Forderung D, Heuwieser W (2002) Do lactoferrin, lysozyme and the lactoperoxidase-thiocyanate-hydrogen peroxide-system cause negative microbiological results in mastitis secretions? Dtsch Tierarztl Wochenschr 109:300-305 
Schmitz S, Pfaffl MW, Meyer HH, Bruckmaier RM (2004) Short-term changes of mRNA expression of various inflammatory factors and milk proteins in mammary tissue during LPS-induced mastitis. Domest Anim Endocrinol 26:111-126

Schott G (1967) Is yogurt manufacture affected by milk from mastitic cows? Dairy Sci Abstr 29:408

Schukken YH, Hertl J, Bar D, Bennett GJ, Gonzalez RN, Rauch BJ, Santisteban C, Schulte HF, Tauer L, Welcome FL, Grohn YT (2009) Effects of repeated gram-positive and gram-negative clinical mastitis episodes on milk yield loss in Holstein dairy cows. J Dairy Sci 92:3091-3105

Seifu E, Buys EM, Donkin EF (2003) Effect of the lactoperoxidase system on the activity of mesophilic cheese starter cultures in goat milk. Int Dairy J 13:953-959

Seifu E, Buys EM, Donkin EF (2005) Significance of the lactoperoxidase system in the dairy industry and its potential applications: a review. Trends Food Sci Technol 16:137-154

Sharma KK, Randolph HE (1974) Influence of mastitis on properties of milk. 8. Distribution of soluble and micellar casein. J Dairy Sci 57:19-23

Sheffield LG (1997) Mastitis increases growth factor messenger ribonucleic acid in bovine mammary glands. J Dairy Sci 80:2020-2024

Shipe WF, Senyk GF (1981) Effects of processing conditions on lipolysis in milk. J Dairy Sci 64:21462149

Shuster DE, Kehrli ME, Baumrucker CR (1995) Relationship of inflammatory cytokines, growthhormone, and insulin-like growth-factor-I to reduced performance during infectious-disease. Proc Soc Exp Biol Med 210:140-149

Shuster DE, Lee EK, Kehrli ME Jr (1996) Bacterial growth, inflammatory cytokine production, and neutrophil recruitment during coliform mastitis in cows within ten days after calving, compared with cows at midlactation. Am J Vet Res 57:1569-1575

Shuster DE, Kehrli ME, Rainard P, Paape M (1997) Complement fragment C5a and inflammatory cytokines in neutrophil recruitment during intramammary infection with Escherichia coli. Infect Immun 65:3286-3292

Singh LN, Ganguli NC (1975) Alterations in the micellar, soluble and other casein fractions in the Serum abnormal bovine milk secretions. Ind J Dairy Sci 28:151-158

Singh K, Dobson J, Phyn C, Davis S, Farr V, Molenaar A (2006) Streptococcus uberis increases apoptosis of bovine mammary epithelial cells (MEC) and decreases integrin and focal adhesion kinase (FAK) mRNA expression. J Anim Sci 84:148

Somers JM, O’Brien B, Meaney WJ, Kelly AL (2003) Heterogeneity of proteolytic enzyme activities in milk samples of different somatic cell count. J Dairy Res 70:45-50

Sordillo LM, Nickerson SC, Akers RM (1989) Pathology of Staphylococcus aureus mastitis during lactogenesis: relationships with bovine mammary structure and function. J Dairy Sci 72:228-240

Suzuki J, Katoh N (1990) Cysteine protease in bovine milk capable of hydrolyzing casein as the substrate and elevation of the activity during the course of mastitis. Jpn J Vet Sci 52:947-954

Swanson KM, Stelwagen K, Dobson J, Henderson HV, Davis SR, Farr VC, Singh K (2009) Transcriptome profiling of Streptococcus uberis-induced mastitis reveals fundamental differences between immune gene expression in the mammary gland and in a primary cell culture model. J Dairy Sci 92:117-129

Tallamy PT, Randolph HE (1970) Influence of mastitis on properties of milk. V. Total and free concentrations of major minerals in skimmilk. J Dairy Sci 53:1386-1388

Tao WJ, Mallard B (2007) Differentially expressed genes associated with Staphylococcus aureus mastitis of Canadian Holstein cows. Vet Immunol Immunopathol 120:201-211

Urech E, Puhan Z, Schallibaum M (1999) Changes in milk protein fraction as affected by subclinical mastitis. J Dairy Sci 82:2402-2411

Vangroenweghe F, Rainard P, Paape M, Duchateau L, Burvenich C (2004) Increase of Escherichia coli inoculum doses induces faster innate immune response in primiparous cows. J Dairy Sci 87:4132-4144

Vangroenweghe F, Duchateau L, Boutet P, Lekeux P, Rainard P, Paape MJ, Burvenich C (2005) Effect of carprofen treatment following experimentally induced Escherichia coli mastitis in primiparous cows. J Dairy Sci 88:2361-2376

Vanselow J, Yang W, Herrmann J, Zerbe H, Schuberth HJ, Petzl W, Tomek W, Seyfert HM (2006) DNAremethylation around a STAT5-binding enhancer in the $\alpha$ S1-casein promoter is associated with abrupt shutdown of $\alpha$ S1-casein synthesis during acute mastitis. J Mol Endocrinol 37:463-477

Vautor E, Cockfield J, Le Marechal C, Le Loir Y, Chevalier M, Robinson DA, Thiery R, Lindsay J (2009) Difference in virulence between Staphylococcus aureus isolates causing gangrenous mastitis versus subclinical mastitis in a dairy sheep flock. Vet Res 40:56-67

Verdi RJ, Barbano DM (1991) Effect of coagulants, somatic-cell enzymes, and extracellular bacterial enzymes on plasminogen activation. J Dairy Sci 74:772-782 
Verdi RJ, Barbano DM, Dellavalle ME, Senyk GF (1987) Variability in true protein, casein, nonprotein nitrogen, and proteolysis in high and low somatic cell milks. J Dairy Sci 70:230-242

Vianna PCB, Mazal G, Santos MV, Bolini HMA, Gigante ML (2008) Microbial and sensory changes throughout the ripening of Prato cheese made from milk with different levels of somatic cells. J Dairy Sci 91:1743-1750

Viguier C, Arora S, Gilmartin N, Welbeck K, O’Kennedy R (2009) Mastitis detection: current trends and future perspectives. Trends Biotechnol 27:486-493

Vivar-Quintana AM, De la Mano EB, Revilla I (2006) Relationship between somatic cell counts and the properties of yoghurt made from ewes' milk. Int Dairy J 16:262-267

Waes G, Belleghem VM (1969) Influence de la mammite sur les propiétés technologiques et sur la qualité des produits laitiers. Lait 49:266-290

Watanabe A, Yagi Y, Shiono H, Yokomizo Y (2000) Effect of intramammary infusion of tumour necrosis factor-alpha on milk protein composition and induction of acute-phase protein in the lactating cow. J Vet Med B Infect Dis Vet Public Health 47:653-662

Watanabe A, Yagi Y, Shiono H, Yokomizo Y, Inumaru S (2008) Effects of intramammary infusions of interleukin-8 on milk protein composition and induction of acute-phase protein in cows during mammary involution. Can J Vet Res 72:291-296

Weaver JC, Kroger M (1977) Protein, casein, and noncasein protein percentages in milk with high somatic cell counts. J Dairy Sci 60:878-881

Wedholm A, Moller HS, Lindmark-Mansson H, Rasmussen MD, Andren A, Larsen LB (2008) Identification of peptides in milk as a result of proteolysis at different levels of somatic cell counts using LC MALDI MS/MS detection. J Dairy Res 75:76-83

Wegner TN, Stull JW (1978) Relation between mastitis test score, mineral composition of milk, and blood electrolyte profiles in Holstein cows. J Dairy Sci 61:1755-1759

Weinrauch Y, Zychlinsky A (1999) The induction of apoptosis by bacterial pathogens. Annu Rev Microbiol 53:155-187

Wickstrom E, Persson-Waller K, Lindmark-Mansson H, Ostensson K, Sternesjo A (2009) Relationship between somatic cell count, polymorphonuclear leucocyte count and quality parameters in bovine bulk tank milk. J Dairy Res 76:195-201

Wilson DJ, Gonzalez RN, Hertl J, Schulte HF, Bennett GJ, Schukken YH, Grohn YT (2004) Effect of clinical mastitis on the lactation curve: a mixed model estimation using daily milk weights. J Dairy Sci 87:2073-2084

Winter P, Schilcher F, Fuchs K, Colditz IG (2003) Dynamics of experimentally induced Staphylococcus epidermidis mastitis in East Friesian milk ewes. J Dairy Res 70:157-164

Ying CW, Wang HT, Hsu JT (2002) Relationship of somatic cell count, physical, chemical and enzymatic properties to the bacterial standard plate count in dairy goat milk. Livest Prod Sci 74:63-77

Zavizion B, White JH, Bramley AJ (1997) Staphylococcus aureus stimulates urokinase-type plasminogen activator expression by bovine mammary cells. J Infect Dis 176:1637-1640

Zeng SS, Escobar EN (1996) Factors affecting somatic cell count of goat milk throughout lactation: parity and milk production, in: The International Symposium on Somatic Cells and Milk of Small Ruminants, Bella, Italy, 25-9-1996, pp 157-160

Zhang S, Maddox CW (2000) Cytotoxic activity of coagulase-negative staphylococci in bovine mastitis. Infect Immun 68:1102-1108

Zhao X, Lacasse P (2008) Mammary tissue damage during bovine mastitis: causes and control. J Anim Sci 86:57-65 